\title{
Composition, biomass and potential grazing impact of the crustacean and pelagic tunicates in the northern Humboldt Current area off Chile: differences between El Niño and non-El Niño years
}

\author{
Humberto E. González ${ }^{1, *}$, Marcus Sobarzo $^{2}$, Dante Figueroa $^{3}$, Eva-Maria Nöthig ${ }^{4}$ \\ ${ }^{1}$ Universidad Austral de Chile, Instituto de Biología Marina, Casilla 567, Valdivia, Chile \\ ${ }^{2}$ Centro EULA-CHILE, Universidad de Concepción, Casilla $156 \mathrm{C}$, Concepción, Chile \\ ${ }^{3}$ Universidad de Concepción, Depto. de Fisica de la Atmósfera y del Océano, Casilla 4009, Concepción, Chile \\ ${ }^{4}$ Alfred Wegener Institute for Polar and Marine Research, Postfach 120161, 27570 Bremerhaven, Germany
}

\begin{abstract}
A multi-disciplinary research program was conducted in the northern Humboldt Current System in a $80 \times 80$ nautical mile area off Antofagasta, northern Chile $\left(23^{\circ} \mathrm{S}\right)$ on 3 occasions: before the $1997 / 98$ El Niño event (January 1997), and during the onset and maximum periods of the event (July 1997 and January 1998, respectively). As a part of this program, the trophodynamic role of pelagic tunicates (salps and appendicularians), as well as the crustacean zooplankton, divided into 3 size classes (large- [euphausiids], medium- [large calanoid copepods] and small-size animals [small calanoid and cyclopoid copepods]) were assessed. One of the most conspicuous physical processes was the deepening of the thermocline during the El Niño event, which in turn led to suppression of nutrient enrichment by upwelling events and low chlorophyll a ( $\mathrm{chl}$ a) concentrations in the study area. Chl $a$ and particulate organic carbon (POC) values were higher near the coast, and coastal/oceanic gradients were greater in the case of chl $a$. High chl a $\left(100\right.$ to $\left.160 \mathrm{mg} \mathrm{m}^{-2}\right)$ and POC $\left(11\right.$ to $\left.17 \mathrm{~g} \mathrm{~m}^{-2}\right)$ concentrations were usually found associated with bays and/or capes within 40 nautical miles of the coast. In contrast. oceanic areas showed low concentrations throughout the study. Small calanoid and cyclopoid copepods represented only a minor fraction of the total crustacean zooplankton carbon ( 4 to $20 \%$ ), although they often accounted for a relatively large portion of the total ingestion ( 26 to $68 \%$ ) of the crustacean zooplankton community. Euphausiids represented a large fraction of total crustacean zooplankton carbon ( 28 to $73 \%$ ), and accounted for between 5 and $61 \%$ of total crustacean zooplankton grazing. Ingestion rate as a percentage of body carbon was negatively correlated with animal size, varying between $4 \%$ in euphausiids (17 mm) and $123 \%$ in small calanoid copepods ( 0.8 to $1.7 \mathrm{~mm})$. A comparison of estimated daily respiration rates and daily carbon ingestion rates indicated that ingestion of phytoplankton would have exceeded respiratory demands for both large and small calanoid copepods during all 3 sampling periods. In contrast, ingestion of phytoplankton failed to account for the respiratory needs of the euphausiids. This, together with microscopical observations, led to the conclusion that euphausiids utilised other sources of carbon such as detritus, micro- and mesozooplankton in addition to phytoplankton. Crustacean zooplankton showed a significant grazing impact, removing from 10 to $34 \%$ of primary production (PP). Salps of the species Salpa fusiformis were present in dense aggregates that could have removed up to $60 \%$ of PP during January 1997. On average, the grazing impact of this species was approximately one-half $(16 \%)$ that of the whole crustacean zooplankton community combined $(34 \%)$. We did not find any significant difference in zooplankton biomass between January 1997 (nonEl Niño) and January 1998 (El Niño), with average biomasses of 24.6 and $21.4 \mathrm{mg}_{\text {dry }} \mathrm{wt} \mathrm{m}^{-3}$, respectively. There was, however, a shift in the size spectrum of crustacean zooplankton towards small-sized copepods between January 1997 (60 $\mathrm{mg} \mathrm{C} \mathrm{m}^{-2}$ ) and January 1998 (186 $\mathrm{mg} \mathrm{C} \mathrm{m}^{-2}$ )
\end{abstract}

KEY WORDS: Ingestion rate $\cdot$ Zooplankton $\cdot$ Antofagasta $\cdot$ Chile $\cdot$ ENSO event

\section{INTRODUCTION}

The coastal area off Antofagasta, like the rest of the northern part of the Chilean sector in the Humboldt Current System (HCS), is influenced by intermittent wind-driven upwelling events having a fertilizing effect and causing high chlorophyll a ( $\mathrm{chl} \mathrm{a}$ ) concentrations in a rather narrow band close to the coast (Thomas et al. 1994, Morales et al. 1996). Within this band, only 1 key species of copepod (Calanus chilensis) 
has been extensively studied (Escribano et al. 1997 and references therein), whereas little knowledge exists on the rest of the zooplankton community.

In upwelling areas carbon flow may occur mainly through 'classical' food webs (Steele 1974), with copepods and euphausiids acting as links between primary production and fish production (Escribano et al. 1997). This scenario contrasts with those of oceanic areas of the northern Humboldt Current where pelagic tunicates are abundant. Here, an important part of the energy flowing from primary producers to fishes passes through (Mianzan et al. 1996) or is modified by (Pagès et al. 1996) gelatinous zooplankton.

The trophodynamic aspects of zooplankton assemblages in the pelagic food web from coastal and oceanic waters off northern Chile are poorly known. Our aim is therefore to provide information about the distribution and abundance of zooplankton in relation to biological, physical and chemical conditions off Antofagasta, Chile. In addition, we examine ingestion rates of different size ranges within the zooplankton community in order to provide insight on the role of these groups in the energy flow through the plankton assemblages off Antofagasta during both non-El Niño and El Niño conditions.

The study took place before (January 1997) and during (July 1997 and January 1998) the development of an El Niño event. It is well known that during an El Niño event strong physical and biological changes take place (Arntz \& Fahrbach 1996). One important consequence of the oceanic El Nin̄o Southern Oscillation (ENSO) cycle mechanisms (Kelvin and Rossby waves) is that wave action alternates between being an upwelling and a downwelling force, creating the reversal from deep (warm, El Niño) to shallow (cold, La Niña) thermocline conditions (Strub et al. 1998). The persistent deepening of the thermocline apparently depresses the upwelling of nutrient-replete Sub-Surface Equatorial Waters which in turn leads to a limitation of nutrient availability and significantly lower primary production. Changes in species composition and a decrease of biomass during an El Niño event have been reported for both phytoplankton (Avaria \& Muñoz 1987) and zooplankton (Carrasco \& Santander 1987).

Plankton from upwelling areas has been investigated mainly on the Peru platform and in the California and Benguela Currents. The Benguela upwelling system is diatom-dominated; however, with the strong stratification and nutrient depletion during quiescent (non-upwelling) periods (Mann 1992), microflagellate populations are dominant (Shannon \& Piller 1986). For the Peruvian coast it has been suggested that it is not the upwelling itself which is disruptive during an El Niño event but the nutrient content of the water which is upwelled (Barber \& Chavez 1983, Huyer et al. 1987), i.e. as the thermocline deepens, the upwelled water is warmer and poorer in nutrients. Significant decreases in zooplankton biomass (from 25 to $6 \mathrm{mI} \mathrm{m}^{-2}$ ), with a dominance of chaetognaths, were described during the 1982/83 El Niño off the coast of Peru (Carrasco \& Santander 1987). These findings cannot be extrapolated to our study area, however, because of profound differences in topography and oceanographic characteristics. More information is required targeted at areas where crustacean zooplankton and/or pelagic tunicates could play a substantial role in the trophodynamics of the pelagic ecosystem.

\section{MATERIALS AND METHODS}

Study area. Measurements were carried out and samples were collected from the coastal and oceanic regions off Antofagasta $\left(23^{\circ} \mathrm{S}, 70^{\circ} \mathrm{W}\right)$ during 3 cruises: (1) austral summer 1997, 11 January to 4 February; (2) austral winter 1997,1 to 25 July 1997 and (3) austral summer 1998,26 to 29 January. In a grid of 31 stations covering ca 6400 square nautical miles (n mile), 8 oceanographic (where physical and biological measurements were taken) and 23 'physical' stations were disposed in 5 transects (T1 to T5) (Fig. 1A). In addition, during July, 3 stations were visited at 120, 160 and $200 \mathrm{n}$ miles from the coast along Transect $3\left(23^{\circ} 20^{\prime} \mathrm{S}\right)$ (Fig. 1B). In 1997, Grid 1 (first leg) was sampled between 11 and 16, and Grid 2 (second leg) between 22 and 27 January. Grid 1 (first leg) was sampled between 30 June and 5 July, and Grid 2 (second leg) between 16 and 21 July 1997 (this grid included only Stns 1 to 19 because the rest of the time was devoted to conducting the $200 \mathrm{n}$ mile transect). During January 1998, only coastal stations (Stns 1, 2 and 3) were sampled.

Measurements at 'time-series' stations (ca 48 h) were conducted after each grid (January and July 1997) in order to estimate vertical flux of particles, faecal pellet production and microzooplankton abundance and distribution in the water column. This information has been reported elsewhere (González et al. 1998).

Two types of stations were sampled: hydrographic and biological stations. At the hydrographic stations continuous profiles of temperature, salinity, dissolved oxygen and fluorescence from the upper $600 \mathrm{~m}$ of the water column were recorded using a CTD (Neil Brown Model MK3, only the upper $300 \mathrm{~m}$ are shown in Fig. 2). Also, water samples were collected at selected depths (mainly within the upper $100 \mathrm{~m}$ of the water column) using Niskin bottles, for the estimation of chl a and carbon concentrations. At the biological stations, in addition to the measurements described for the hydrographic stations, zooplankton abundance 
Fig. 1 The study area showing (A) the position of the physical (•) and oceanographic (回) stations along Transects 1 to 5 (T1 to T5) in waters off Antofagasta and (B) the position of the 120 , 160 and 200 nautical miles (n mile) stations visited during July 1997
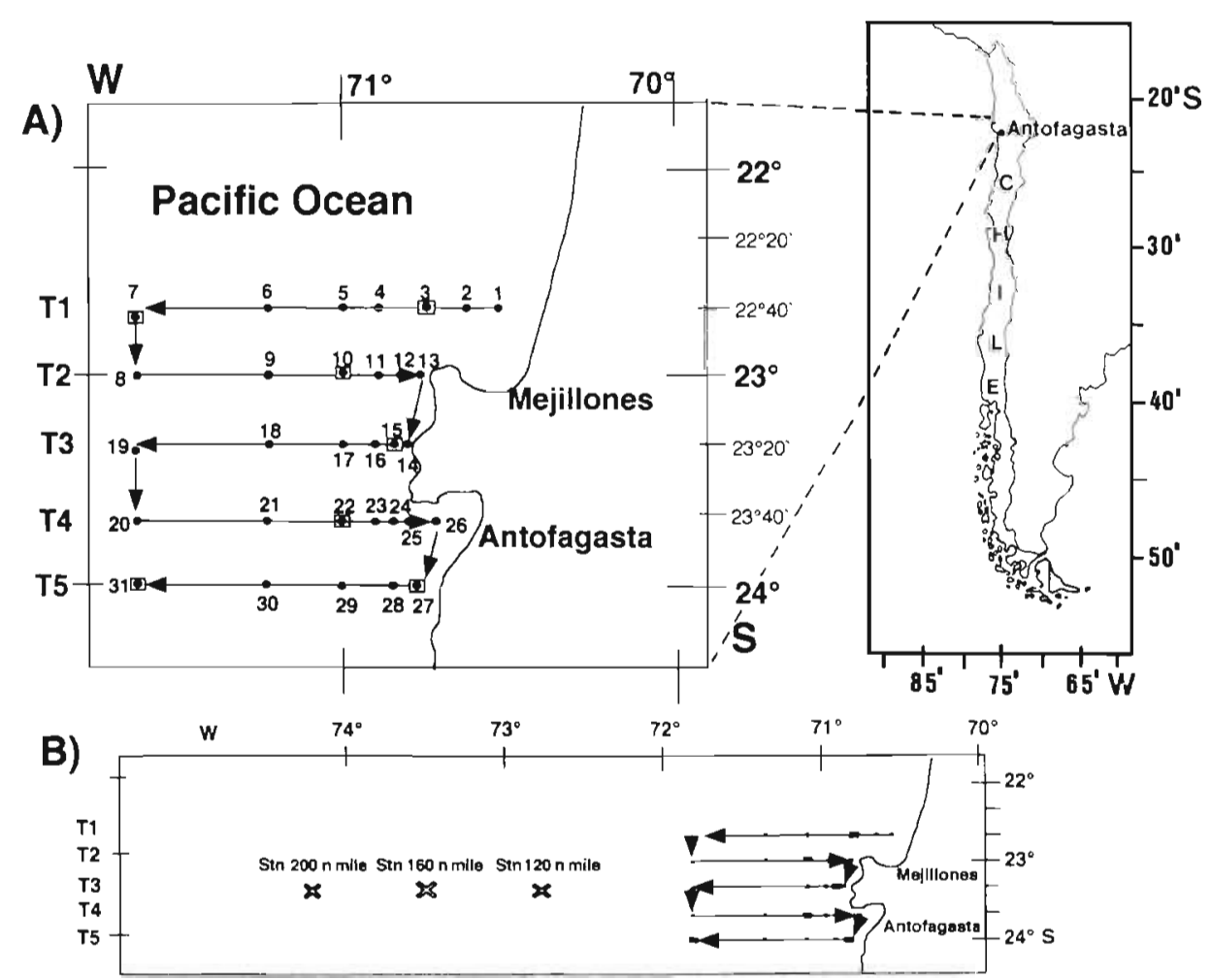

was estimated and specimens for experiments were collected.

$\mathrm{Chl} \mathbf{a}$ and carbon. Samples were collected from the upper $100 \mathrm{~m}$ of the water column at selected depths: usually $2,10,20,50$ and $100 \mathrm{~m}$. In addition, when a conspicuous fluorescence maximum was present at a depth other than those selected, that depth was also sampled. From 150 to $500 \mathrm{ml}$ were filtrated in GF/F filters (Whatman ${ }^{\circledR}$ ). Chl a was measured by fluorometry (Parsons et al. 1992) using a Turner Design fluorometer (Model AU-10). Sub-samples of water were collected from the same Niskin bottles in order to measure particulate organic carbon (POC). After filtration of $1 \mathrm{l}$ of water through a pre-combusted GF/F filter and acidification in a fume box, POC was determined by using a Carlo Erba Carbon Analyzer 1500 with acetanilide as standard (Bodungen et al. 1991). Individuals from different zooplankton taxa and copepod/euphausiid faecal pellets were also placed on pre-combusted $\mathrm{GF} / \mathrm{F}$ filters, rinsed with distilled water and their carbon content was determinated as described above.

Zooplankton abundances. Zooplankton was collected from 2 depth strata 0 to $50 \mathrm{~m}$ and 50 to $150 \mathrm{~m}$ ) and 1 integrated stratum (0 to $150 \mathrm{~m}$ ) using a $1 \mathrm{~m}^{2}$ Tucker trawl net equipped with 3 nets $(200 \mu \mathrm{m}$ mesh size) and a flow-meter. The $50 \mathrm{~m}$ depth corresponds more or less to the boundary between the upper SubTropical Water (STW) and the Sub-Antarctic Water (SAW) which occupies a narrow band centered at $50 \mathrm{~m}$ depth. Below 50 to $70 \mathrm{~m}$ we found Sub-Surface Equatorial Water (SSEW) which extends down to a $400 \mathrm{~m}$ depth. Samples were preserved in formalin $(4 \%$ end concentration). Zooplankton was sorted and counted using a stereomicroscope (Wild M8). Only crustacean zooplankton, appendicularians, salps and chaetognaths were examined in this study. During the timeseries studies, echosound observations (upper $400 \mathrm{~m}$ water column) were carried out simultaneously with zooplankton sampling to describe the vertical migration of euphausiids.

Gut pigment measurements of copepods and krill. The ingestion rate (IR) of phytoplankton by the dominant zooplankton size classes was determined using the gut-fluorescence method (Mackas \& Bohrer 1976). Immediately after capture, in order to also be able to estimate the gut clearance rate (GCR) constant, the whole zooplankton sample was placed in a $50 \mathrm{l}$ container filled with filtered seawater $(0.45 \mu \mathrm{m})$, from which sub-samples were taken with a small sieve at 0 , $5,15,30,45,60,90,120,180$ and 240 min after collection. Each sub-sample was first placed for a few minutes in liquid nitrogen and then stored in a deep-freeze $\left(-30^{\circ} \mathrm{C}\right)$. For analysing gut pigments at the different times, 3 (large krill) to 200 (cyclopoid copepods) individuals were placed in $8 \mathrm{ml}$ acetone $(90 \% \mathrm{v} / \mathrm{v})$ for pigment extraction. Fluorescence of the extract was determined with a Turner-Design fluorometer (Model AU-10). Concentrations of chl $a$ and phaeopigments 
were calculated using the equations of Parsons et al. (1992). Starved animals were used to correct the values due to background fluorescence.

Chl $a$ and its degradation products serve as naturally occurring tracers, only if they can be measured fluorometrically. However, the presence of chlorophyllbleaching enzymes from both animals and phytoplankton have been reported (Head \& Harris 1996) which might lead to degrees of pigment destruction (to colorless compounds) close to $100 \%$ in areas characterized by low pigment concentrations, at low zooplankton ingestion rates (Stevens \& Head 1998). As our study area partially exhibits these characteristics, we applied a correction factor in our IR measurements according to the relationship between real and apparent IRs (Fig. 10 of Stevens \& Head 1998). Thus, the correction factor varied from 2 for euphausids during January 1997 to 10 for large-size copepods during July 1997. In all cases, because of the uncertainties involved in the use of this model (see 'Discussion'), we reported the original (uncorrected) as well as corrected estimations of IR.

In order to estimate abundance and IR by size categories, animals were pooled according to size ranges in 3 categories: large, medium and small animals. Large animals were represented by euphausiids (mainly Euphausia mucronata and E. eximia). Animals collected in January ranged in length from 9 to $23 \mathrm{~mm}$ (mean $=17 \mathrm{~mm})$, while those collected in July were from 7 to $19 \mathrm{~mm}$ (mean $=11 \mathrm{~mm}$ ). Medium-sized animals were represented by calanoid copepods, mainly CIV stage to adults of Centropages spp. with a mean length of $1.75 \mathrm{~mm}$, Calanus chilensis with a mean length of $2.2 \mathrm{~mm}$, and Rhincalanus spp. and Eucalanus spp. with mean lengths of $2.0 \mathrm{~mm}$. Small animals were represented by small calanoid copepods, mainly Temora spp., Acartia spp., Microcalanus spp., Paracalanus spp. and $\mathrm{CI}$ to CIII stages of the genera Calanus and Centropages with a length range of 0.8 to $1.5 \mathrm{~mm}$. The cyclopoid copepods Corycaeus spp., Oithona spp. and Oncaea spp. with a length range of 0.7 to $1.2 \mathrm{~mm}$, also belong to this size class.

Gut content (GC) and the GCR constant of animals were used to calculate IR in nanograms of chl a equivalents (the sum of chl $a$ and phaeopigments) per individual and time. Animals that were easily recognized and, thus, quickly sorted out under the stereomicroscope because of their large size (euphausiids) or high abundance and distinct shape (cyclopoid copepods) were analysed separately. Species or groups for which separation would have been time consuming because of their morphological similarity, high abundance and diversity, such as large-, medium- and small-size calanoid copepods, were treated as a size class and chosen at random.
A C:chl a ratio was determined from water samples collected at selected depths within the upper $50 \mathrm{~m}$ of the water column (usually 2, 10, 20, $50 \mathrm{~m}$ and sometimes at the chl a maximum), and used to convert this IR into units of carbon assuming no selectivity. In the context of this study (i.e. a carbon flux approach within zooplankton size classes) this assumption seems generally reasonable as pelagic tunicates are non-selective (Madin \& Deibel 1998) and crustaceans may be, although the latter case is not as straightforward because feeding strategies are very complex and may change in response to environmental variability and ontogenetic stages (see Stuart \& Pillar 1990 for euphausiids, Kleppel 1993 for copepods). We chose to use an average C:chl a ratio for the upper $50 \mathrm{~m}$ of the water column and not the value at the depth of the chl a maximum because we collected animals by means of integrated net tows within the upper $50 \mathrm{~m}$ layer. In addition, echosound observations showed a relatively homogeneous 0 to $50 \mathrm{~m}$ scatter-layer due to plankton, indicating that the animals were relatively evenly distributed.

The percentage of the daily primary production (PP) grazed by copepods, euphausiids, salps and appendicularians was calculated using the PP data determined at the same stations (González et al. 1998). As the purpose of this study was to assess the overall grazing pressure exerted by zooplankton distributed in the different size categories in the coastal and oceanic areas off Antofagasta, we used average values of IR for each of the different size classes within each sampling period. Since we know that euphausiid species perform diel vertical migrations, we used integrated values of abundance in the upper $150 \mathrm{~m}$ of the water column and we pooled all data (day and night catches).

Ingestion rates in pelagic tunicates. These rates were derived from literature data. The mean daily ration for a $16 \mathrm{~mm}$ Salpa fusiformis blastozooid is $1.07 \mu \mathrm{g} \mathrm{C \mu g} \mathrm{g}^{-1} \mathrm{~d}^{-1}$ (Andersen 1985). As the average carbon content for a $32 \mathrm{~mm} S$. fusiformis is $366 \mu \mathrm{g}$ (see Fig. 6), their potential daily ingestion is estimated to be $403 \mu \mathrm{g} \mathrm{C}$. The feeding rate values for $S$. fusiformis determined using Andersen's constant are low compared to rates for congeneric species (Madin \& Deibel 1998), so estimates of the impact of this species may be quite conservative. An average Oikopleura dioica individual $(0.6 \mathrm{~mm}$, long range 0.5 to $0.8 \mathrm{~mm}$ ) contained $0.734 \mathrm{ng}$ pigment. Given a gut evacuation rate of $0.86 \mathrm{~h}^{-1}$ (Acuña \& Deibel 1994) and continuous feeding over $24 \mathrm{~h}$ (Alldredge 1981), the estimated IR would be 15 ng pigment $d^{-1}$. In salps, about half of the ingested pigment is lost during gut passage (Madin \& Purcell 1992). Assuming that this factor applies to appendicularians (Deibel 1997), an IR of $30 \mathrm{ng}$ pigment $\mathrm{d}^{-1}$ can be expected. As the average in situ C:Chl a ratio was 123 , a daily ingestion of POC equal to $3.7 \mathrm{~kg}$ was used. 


\section{RESULTS}

\section{Oceanographic conditions}

During January 1997, cross-sections of temperature and dissolved oxygen (Fig. 2A,B) showed that isolines rose from about $80 \mathrm{~m}$ depth to the surface vicinity within 30 to $40 \mathrm{n}$ miles of the coast. The ascent of the $13^{\circ} \mathrm{C}$-isotherm set a rather shallow (ca $20 \mathrm{~m}$ ) thermocline within $20 \mathrm{n}$ miles of the coast and a distinct inshore-offshore thermal gradient was observed (Fig. 2A). Two water masses with salinities $>34.6 \mathrm{psu}$ occurred above and below the 'upper minimum of salinity' (Silva \& Konow 1975), which also ascended towards the coast. The upper layer was characterized by high salinity surface water (>35 psu), which corresponded to the STW with dissolved oxygen concentrations $>5 \mathrm{ml} \mathrm{l}^{-1}$. The deeper layer was characterized by high salinity, nutrient-rich, sub-surface water, which corresponded to the SSEW, and had an upper limit around 50 to $80 \mathrm{~m}$ and a lower limit at around 400 to $450 \mathrm{~m}$ (not shown). The SSEW ascend closer to the surface $(-25 \mathrm{~m})$ near the coast as revealed by the minimal values of dissolved oxygen $\left(<2 \mathrm{ml} \mathrm{l}^{-1}\right)$ usually associated with this water mass. A sharp and shallow oxycline near the coast, which deepened and widened towards the open ocean, separated the oxygenated surface layers from the sub-oxic $\left(<1 \mathrm{ml} \mathrm{l}^{-1}\right)$ SSEW (Fig. 2B).

During the July 1997 cruise, when stations up to $200 \mathrm{n}$ miles offshore were sampled, the isotherms showed a marked deepening from ca $60 \mathrm{n}$ miles towards the coast (Fig. 2C). The $15^{\circ} \mathrm{C}$-isotherm, which during summer was located near the surface, was found at ca $200 \mathrm{~m}$ depth in the coastal area during winter. Further offshore ( $>70 \mathrm{n}$ miles from the coast) the thermocline occurred at between 50 and $70 \mathrm{~m}$ depth;
A) Temperature ( ${ }^{\circ} \mathrm{C}$, January 1997$)$

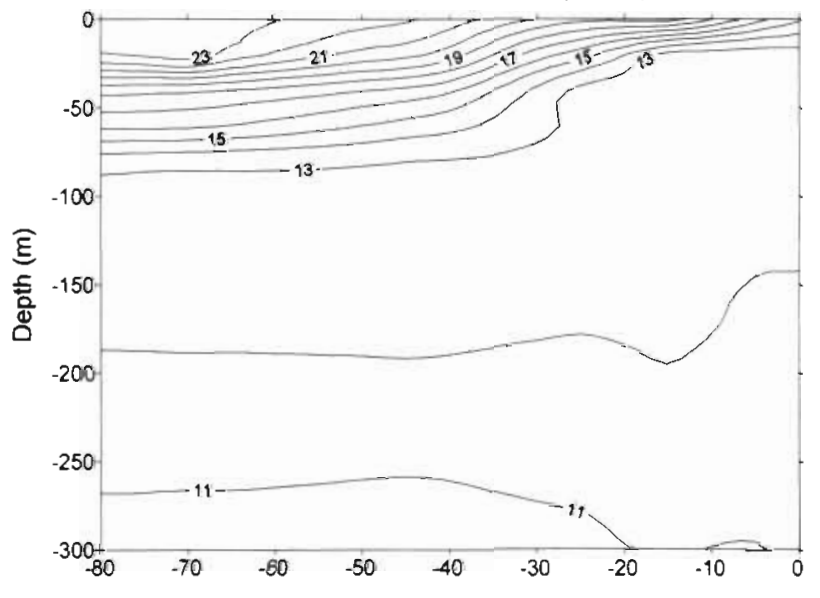

C) Temperature $\left({ }^{\circ} \mathrm{C}\right.$, July 1997$)$

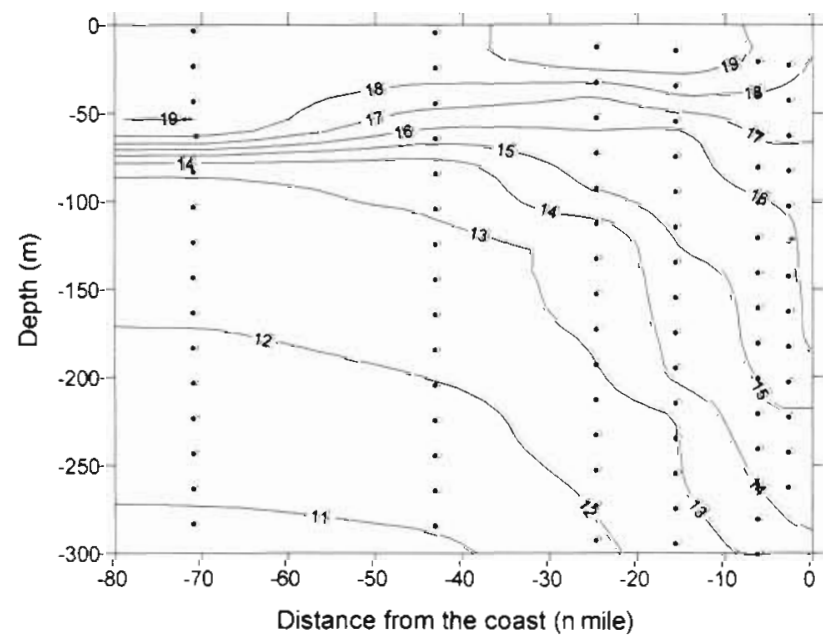

8) Dissolved oxygen ( $\mathrm{m} / \mathrm{l}$, January 1997)

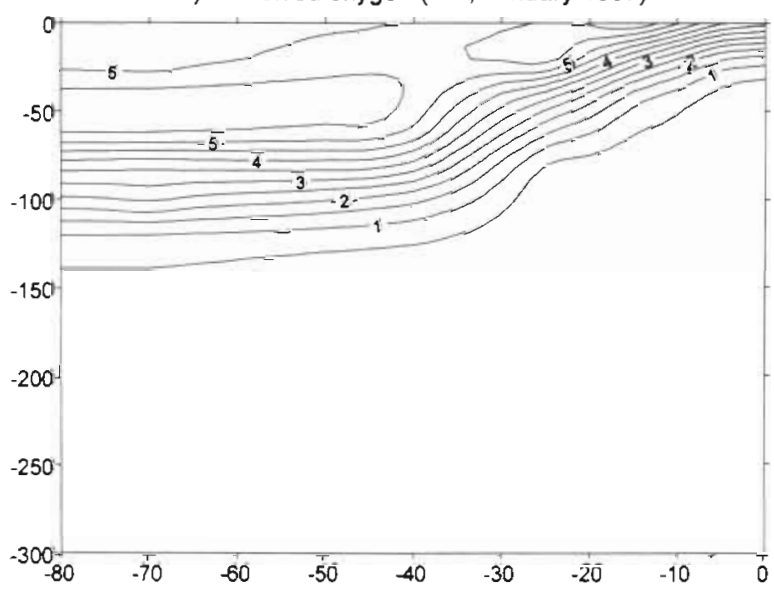

D) Dissolved oxygen (ml/l, July 1997)

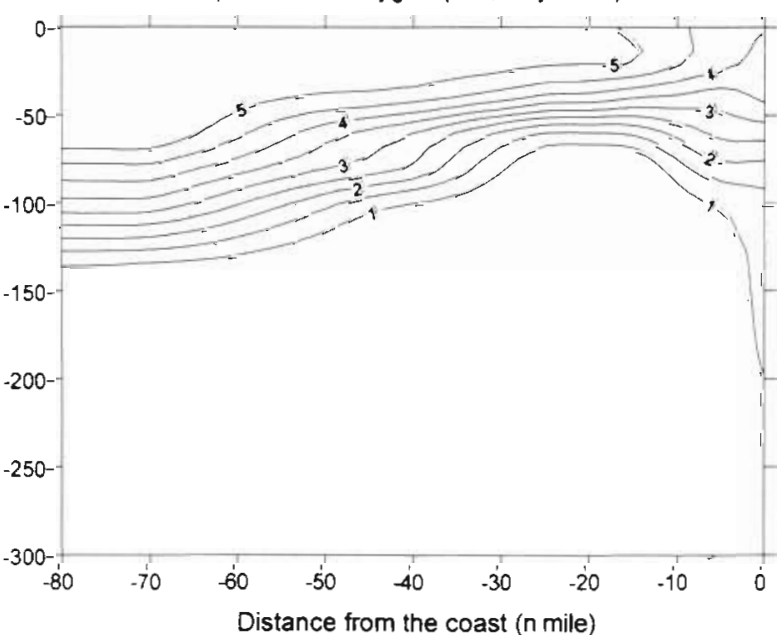

Fig. 2. Cross-sections of isolines of (A) temperature and (B) dissolved oxygen along Transect 3 during January 1997 (second leg), and cross-sections of isolinies of (C) temperature and (D) dissolved oxygen along Transect 3 during July 1997 (second leg). Sampling depths are shown only in (C) 
A) Chl-a, January 1997 (Grid 1)

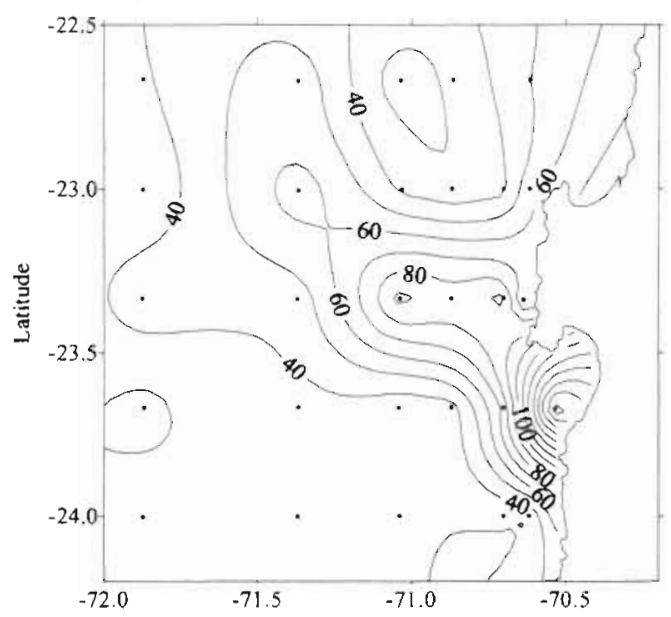

C) Chl-a, July 1997 (Grid l)

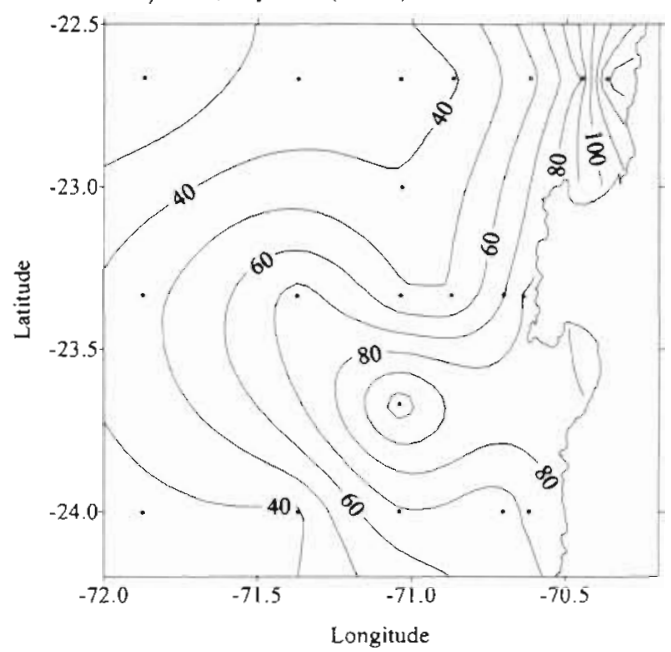

B) Chl-a, January 1997 (Grid 2)

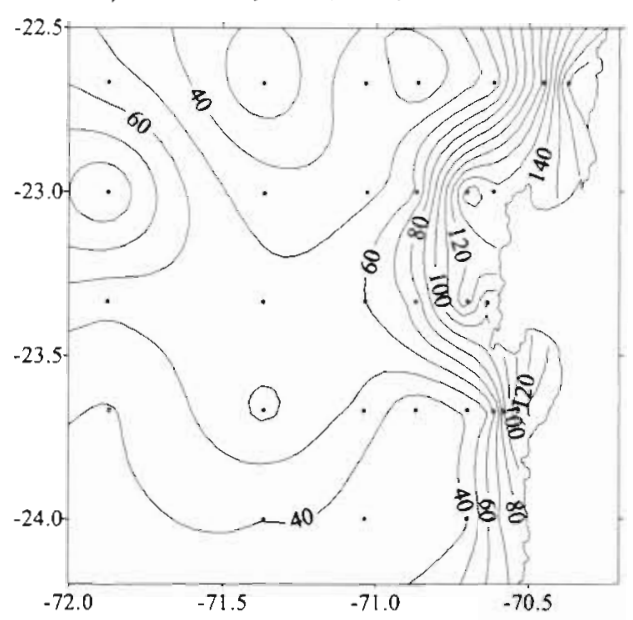

D) Chl-a, July 1997 (Grid 2)

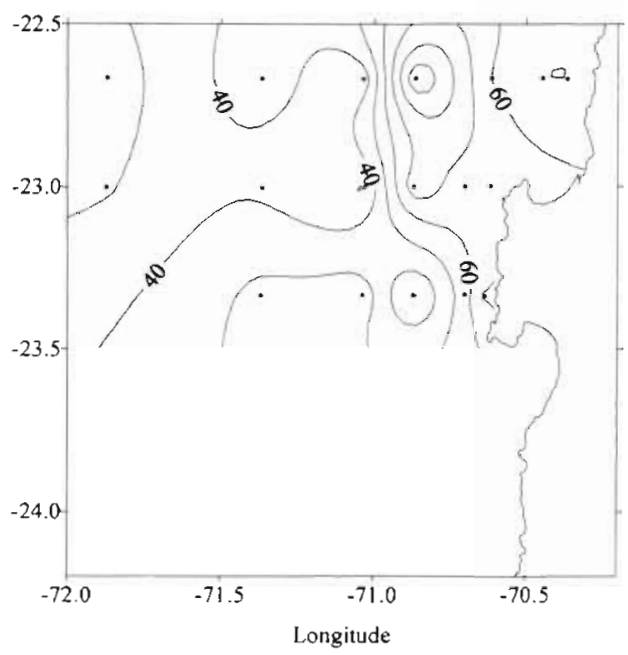

Fig. 3. Integrated (upper $100 \mathrm{~m}$ water column) values of chlorophyll a $\left(\mathrm{mg} \mathrm{m}^{-2}\right)$ during $(A, C)$ Legs 1 and $(B, D) 2$ of the January (upper panels) and July (bottom panels) 1997 cruises inshore it sunk down to ca $200 \mathrm{~m}$ depth. The warm waters close to the coast were characterized by high salinity (>34.8 psu) and values of dissolved oxygen ranging from $\sim 0$ to $4.5 \mathrm{ml} \mathrm{l}^{-1}$ (Fig. 2D).

\section{Chl $\mathrm{a}$ and POC distributions}

Chl a concentrations (integrated down to $100 \mathrm{~m}$ depth) in the water column showed high values (100 to $160 \mathrm{mg} \mathrm{m}^{-2}$ ) closer to the coast and were usually associated with embayments such as Mejillones Bay in the north and Antofagasta Bay in the south (Fig. 3). During January 1997 low integrated concentrations of chl a (30 to $50 \mathrm{mg} \mathrm{m}^{-2}$ ) characterized oceanic stations with a gradual increment towards the coast where values between 60 and $160 \mathrm{mg} \mathrm{m}^{-2}$ were found. The chl $a$ isolines seem to follow a meandering plume which extends from Antofagasta Bay towards offshore areas (Fig. 3A). This distribution fits well with those of cold water filaments extending from the coast up to $200 \mathrm{n}$ miles offshore (González et al. 1998). During the second leg in January 1997, a high chl a concentration band associated with embayments and the Mejillones Peninsula appeared (Fig. 3B). During July 1997. patches of high chl a concentration were sparsely found during the first leg (Fig. 3C), while during the second leg, the high chl a concentration band located close to the coast had disappeared (Fig. 3D).

Chl $a$ and phaeopigment concentrations at 3 depths at the time-series stations, both oceanic (Stn 19) and coastal (Stns 15 and 24), are shown in Table 1. At the oceanic Stn 19, chl a concentrations between 0.2 and $0.4 \mathrm{\mu g} \mathrm{l}^{-1}$ were measured at $2 \mathrm{~m}$ depth, usually with a vertical pattern showing a sub-surface maximum at $40 \mathrm{~m}$ depth characterized by concentrations between 0.3 and $0.5 \mu \mathrm{g} \mathrm{l}^{-1}$. Chl $a$ and phaeopigment concentrations near the surface (2 $\mathrm{m}$ depth) were lower in January $\left(0.2\right.$ and $0.03 \mu \mathrm{g} \mathrm{l}^{-1}$, respectively) than in July 1997 (0.4 and $0.1 \mathrm{ug} \mathrm{l}^{-1}$, respectively). At coastal stations, 
Table 1. Chlorophyll $a$ and phaeopigment concentrations $\left(\mu \mathrm{g} \mathrm{I}^{-1}\right.$; average, SD in parentheses) at 3 depths $(2,40$ and $100 \mathrm{~m})$ at the time-series stations during January and July 1997

\begin{tabular}{|c|c|c|c|c|}
\hline Station & Date & $\begin{array}{l}\text { Depth } \\
\text { (m) }\end{array}$ & $\begin{array}{l}\text { Chlorophyll a } \\
\qquad\left(\mu \mathrm{gl}^{-1}\right)\end{array}$ & $\begin{array}{c}\text { Phaeopigments } \\
\left(\mu \mathrm{gl}^{-1}\right)\end{array}$ \\
\hline \multicolumn{5}{|c|}{ January 1997} \\
\hline $\begin{array}{l}19 \\
\text { (oceanic) }\end{array}$ & $16-17,27$ & $\begin{array}{r}2 \\
40 \\
100\end{array}$ & $\begin{array}{l}0.17(0.06) ; \mathrm{n}=7 \\
0.33(0.07) ; \mathrm{n}=7 \\
0.11(0.02) ; \mathrm{n}=7\end{array}$ & $\begin{array}{l}0.03(0.01) ; \mathrm{n}=6 \\
0.10(0.04) ; \mathrm{n}=6 \\
0.06(0.01) ; \mathrm{n}=6\end{array}$ \\
\hline $\begin{array}{l}24 \\
\text { (coastal) }\end{array}$ & $19-20$ & $\begin{array}{r}2 \\
40 \\
100\end{array}$ & $\begin{array}{l}5.20(2.13) ; n=4 \\
1.08(0.98) ; n=4 \\
0.46(0.05) ; n=4\end{array}$ & $\begin{array}{l}2.44(1.19) ; n=4 \\
0.29(0.09) ; n=4 \\
0.35(0.08) ; n=4\end{array}$ \\
\hline $\begin{array}{l}15 \\
\text { (coastal) }\end{array}$ & $28-31$ & $\begin{array}{r}2 \\
40 \\
100\end{array}$ & $\begin{array}{l}4.91(3.39) ; \mathrm{n}=5 \\
1.17(0.22) ; \mathrm{n}=5 \\
0.49(0.28) ; \mathrm{n}=5\end{array}$ & $\begin{array}{l}1.22(1.19) ; \mathrm{n}=6 \\
0.89(0.57) ; \mathrm{n}=6 \\
0.83(0.41) ; \mathrm{n}=6\end{array}$ \\
\hline \multicolumn{5}{|l|}{ July 1997} \\
\hline $\begin{array}{l}19 \\
\text { (oceanic) }\end{array}$ & $5-6$ & $\begin{array}{r}2 \\
40 \\
100\end{array}$ & $\begin{array}{l}0.35(0.08) ; n=4 \\
0.49(0.08) ; n=4 \\
0.09(0.07) ; n=4\end{array}$ & $\begin{array}{l}0.11(0.03) ; n=4 \\
0.17(0.05) ; n=4 \\
0.06(0.04) ; n=4\end{array}$ \\
\hline $\begin{array}{l}15 \\
\text { (coastal) }\end{array}$ & $8-13$ & $\begin{array}{r}2 \\
40 \\
100\end{array}$ & $\begin{array}{l}1.46(0.85) ; n=7 \\
0.52(0.30) ; n=7 \\
0.28(0.22) ; n=7\end{array}$ & $\begin{array}{l}0.40(0.06) ; \mathrm{n}=7 \\
0.24(0.10) ; \mathrm{n}=7 \\
0.20(0.09) ; \mathrm{n}=7\end{array}$ \\
\hline $\begin{array}{l}15 \\
\text { (coastal) }\end{array}$ & $21-22$ & $\begin{array}{r}2 \\
40 \\
100\end{array}$ & $\begin{array}{l}1.78(0.46) ; \mathrm{n}=3 \\
0.66(0.34) ; \mathrm{n}=3 \\
0.15(0.04) ; \mathrm{n}=3\end{array}$ & $\begin{array}{l}0.72(0.05) ; n=3 \\
0.33(0.15) ; n=3 \\
0.12(0.06) ; n=3\end{array}$ \\
\hline
\end{tabular}

chl a concentrations at $2 \mathrm{~m}$ depth were higher in January (ca $5.0 \mathrm{\mu g} \mathrm{l}^{-1}$ ) than in July 1997 (ca $1.6 \mu \mathrm{g} \mathrm{l}^{-1}$ ).

While a weak sub-surface $(40 \mathrm{~m}$ depth) pigment maximum occurred at the oceanic station on both occasions, there was a continuous decrease in chl a concentration from 2 to $100 \mathrm{~m}$ depth at the coastal stations (ca 5 to $0.5 \mu \mathrm{g} \mathrm{l}^{-1}$ in January 1997 and from ca 2 to $0.2 \mu \mathrm{g} \mathrm{l}^{-1}$ in July 1997). At the coastal stations, phaeopigment concentrations decreased slowly from 40 to $100 \mathrm{~m}$ depth and at 1 station (Stn 24, January 1997) it increased from $0.29 \mathrm{~g} \mathrm{~g} \mathrm{l}^{-1}$ at $40 \mathrm{~m}$ depth to $0.35 \mathrm{\mu g} \mathrm{l}^{-1}$ at $100 \mathrm{~m}$ depth (Table 1 ).

Integrated POC concentrations in the water column ( 0 to $100 \mathrm{~m}$ ) during January 1997 showed maximum values located north and south of the Mejillones Peninsula with values up to $19 \mathrm{~g} \mathrm{~m}^{-2}$ in Mejillones Bay which decreased down to $9 \mathrm{~g} \mathrm{~m}^{-2}$ in oceanic waters (Fig. 4A). During July 1997, POC values were slightly lower than during January, with higher concentrations close to the coast (between 9 and $13 \mathrm{~g} \mathrm{~m}^{-2}$ ) which decreased progressively towards oceanic waters $>20 \mathrm{n}$ miles from the coast ( 7 to $9 \mathrm{~g} \mathrm{~m}^{-2}$ ) (Fig. $4 \mathrm{~B}, \mathrm{C}$ ). In addition, a clear south-north gradient occurred in the oceanic area during Grid 2 (Fig. 4C).

Along the $200 \mathrm{n}$ mile transect, the contoured profiles of chl a concentration showed values between 0.1 and $0.4 \mathrm{mg} \mathrm{m}^{-3}$ below $50 \mathrm{~m}$, except at the $200 \mathrm{n}$ mile station, where values $<0.4 \mathrm{mg} \mathrm{m}^{-3}$ reached the surface.
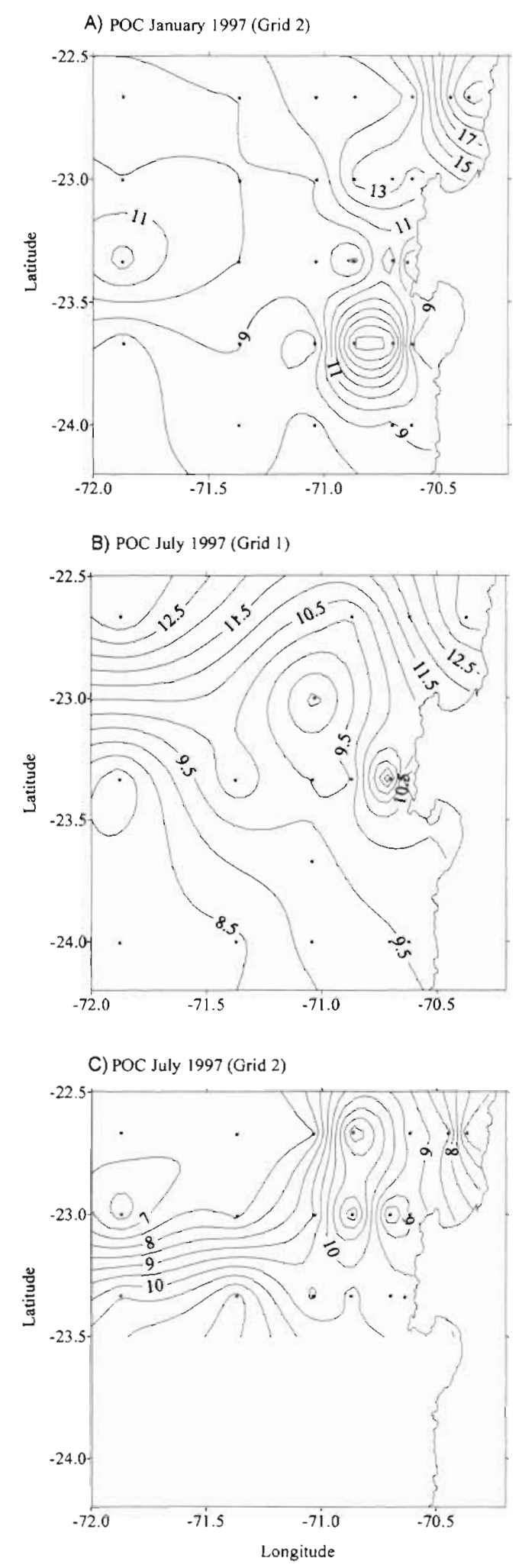

Fig. 4. Integrated (upper $100 \mathrm{~m}$ water column) values of particulate organic carbon $\left(\mathrm{POC}_{\mathrm{i}} \mathrm{g} \mathrm{m}^{-2}\right.$ ) during Leg 2 of the cruise conducted during January 1997 (upper panel) and Legs $1 \& 2$ of the cruise conducted during July 1997 (bottom panels) 

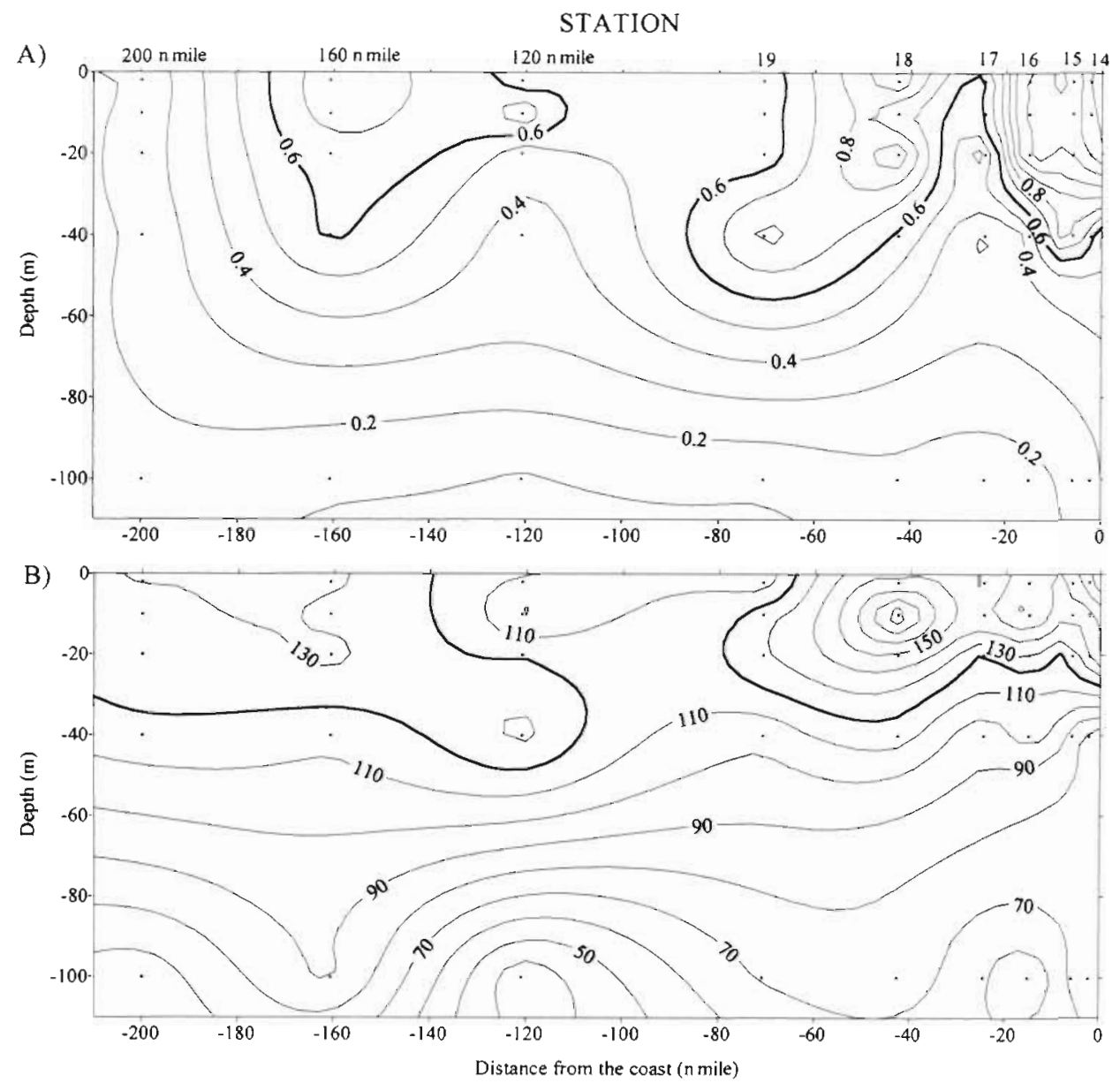

Fig. 5. Cross-sections along Transect 3 showing the isolines of $(A)$ chlorophyll a (in $\mu \mathrm{gl}^{-1}$ ) and (B) POC (in $\mu \mathrm{I}^{-1}$ ) during July 1997

Close to the coast, values of up to $1.2 \mathrm{mg} \mathrm{m}^{-3}$ were found near the surface (Fig. 5A). Isolines tended to deepen, following the distribution pattern of other physical variables such as temperature and dissolved oxygen (Fig. 2C,D). The cross-section of POC showed higher values (130 to $180 \mathrm{mg} \mathrm{m}^{-3}$ ) near the surface (upper $20 \mathrm{~m}$ of the water column) and within $40 \mathrm{n}$ miles of the coast (Fig. 5B). In general, cross-sections of chl a and POC showed slightly higher concentrations closer to the coast than offshore.

\section{Carbon content of zooplankton groups}

Carbon content per individual of different zooplanktonic taxa is depicted in Fig. 6. Cyclopoid copepods represented by individuals of the genera Corycaeus and Oncaea in the length range of 0.7 to $1.2 \mathrm{~mm}$ showed the lowest carbon content per individual (average $\pm \mathrm{SD}: 3.5 \pm 0.3 \mu \mathrm{g}$ ). At the other extreme of the spectrum, euphausiids in the size range of 21 to $24 \mathrm{~mm}$ showed the highest carbon content per individual $(4507 \pm 673 \mu \mathrm{g})$.
Zooplankton biomass (total dry wt) did not show significant differences between January 1997 and January 1998 at the coastal stations (Fig. 7A), but there was a marked shift towards small size classes of zooplankton as the El Niño event progessed (Fig. 7B).

\section{Zooplankton assemblages}

The large-sized crustacean zooplankton population was dominated by euphausiids, mainly Euphausia mucronata and E. eximia. During pre-El Niño conditions (January 1997) at Stn 15 (coastal), the euphausiid abundance during the night was higher in the upper $50 \mathrm{~m}$ of the water column (53.6 ind $\mathrm{m}^{-3}$ ) than in the 50 to $150 \mathrm{~m}$ layer $\left(0.4\right.$ ind. $\mathrm{m}^{-3}$ ). During El Niño (July 1997 and January 1998) a dramatic decrease in euphausiid abundance was noted, with concentrations of ca 2.3 ind $\mathrm{m}^{-3}$ during the night in the upper $50 \mathrm{~m}$ of the water column (Table 2). Echosound observations demonstrated that during January and July euphausidds displayed marked vertical migrations starting to ascend from ca $300 \mathrm{~m}$ depth at $\sim 19: 00 \mathrm{~h}$ up to depths $<50 \mathrm{~m}$. 


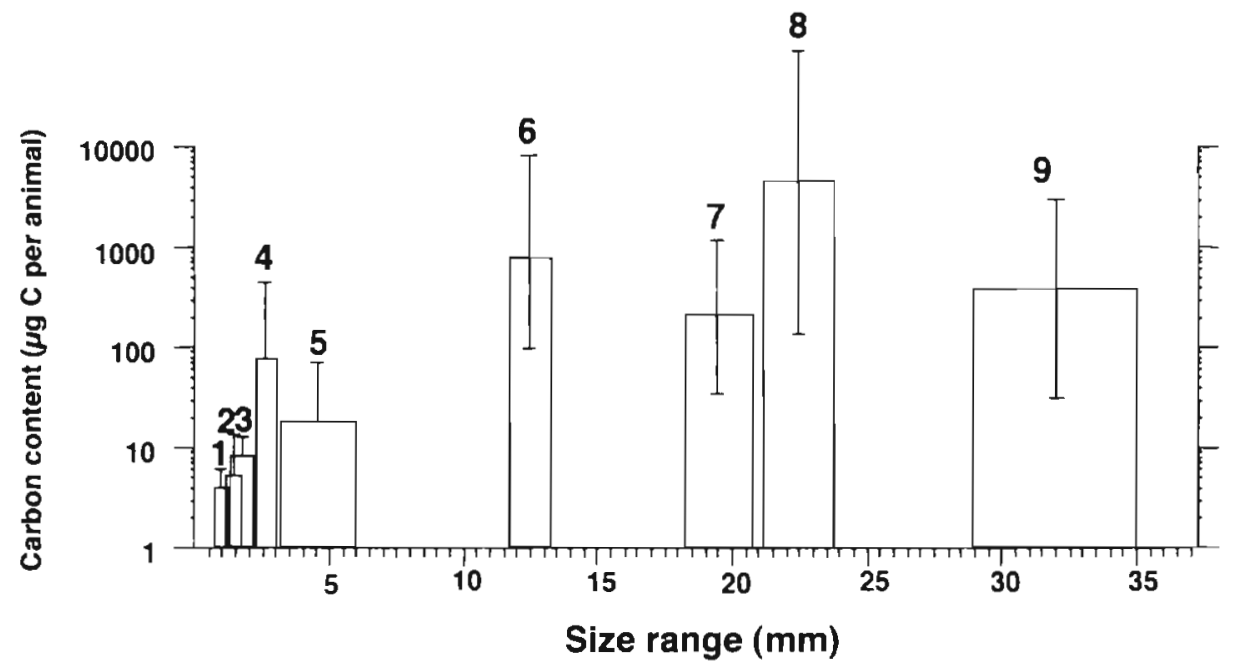

Fig. 6. Carbon content ( $\mu \mathrm{g}$ ind ${ }^{-1}$ ) of size-distributed zooplanktonic taxa or assemblages (note log scale for the ordinate). Error bars denote standard deviation $(n=4)$

\author{
1: Cyclopoid copepods (Corycaeus spp. and Oncaea spp. prosome length [p 1.]) \\ 2: Small calanoid copepods (i. e. Microcalanus spp., Acartia spp., copepodites of Temora spp., Calanus spp. p. I.) \\ 3. Appendicularians (Oikopleura spp. trunk length) \\ 4: Medium-sıze animals: large-size calanoid copepods (i. e Calanus chılensis. Centropages spp. , Eucalanus spp. p.l) \\ 5: Siphonophores (Bassia sp. eudoxid high) \\ 6: Euphausids (mainly Euphaussia mucronata ca. $11 \mathrm{~mm}$ length) \\ 7 Chaetognaths (mainly Sagitta $\mathrm{spp}$. body length) \\ 8. Euphausiids (mainly Euphausia mucronata ca. $17 \mathrm{~mm}$ length) \\ 9: Salps (blastozooids of Salpa fusiformiș)
}

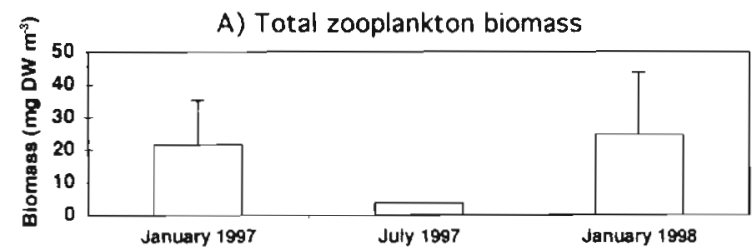

B) Percentage of total zooplankton carbon

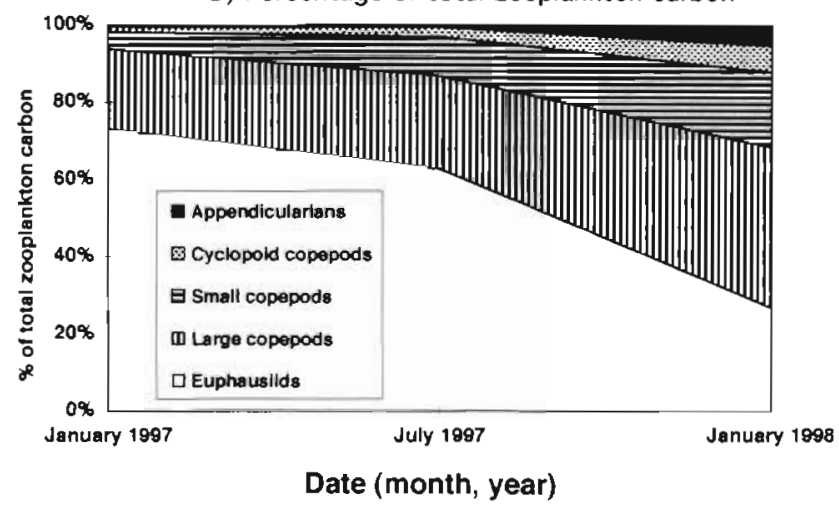

Fig. 7. (A) Averaged zooplankton biomass (mg dry wt $\mathrm{m}^{-3}$, upper $150 \mathrm{~m}$ of the water column) for samples collected at coastal stations during January $1997(\mathrm{n}=5)$, July $1997(\mathrm{n}=3$ ) and January $1998(n=16)$. Error bars denote standard deviation. (B) Carbon distribution (\%) among different size classes of crustacean zooplankton and appendicularians for samples collected at coastal stations during January $1997(\mathrm{n}=5$ ), July $1997(n=3)$ and January $1998(n=16)$
They remained in the upper layer during the night and started to descend at ca 06:00 h. Abundances were highly variable, ranging from 187 ind. $\mathrm{m}^{-2}$ at $\mathrm{Stn} 15$ to 1932 ind. $\mathrm{m}^{-2}$ at $\mathrm{Stn} 22$ during January 1997. During July, concentrations fluctuated between 51 ind. $\mathrm{m}^{-2}$ at Stn 15 and 1964 ind. $\mathrm{m}^{-2}$ at Stn 13, while during January 1998, lower values were found which ranged between 35 and 671 ind. $\mathrm{m}^{-2}$. At the time-series Stn 15 (29 January to 1 February 1997), average ( $(\mathrm{SD}$ ) abundance of euphausiids during day and night catches in the 0 to $50 \mathrm{~m}$ stratum were $2.7( \pm 2 ; \mathrm{n}=3)$ and $29.6( \pm 37$; $\mathrm{n}=4)$ ind. $\mathrm{m}^{-3}$, respectively, while in the 50 to $150 \mathrm{~m}$ stratum they were $6.8( \pm 6 ; n=3)$ and $0.1( \pm 0.1 ; n=4)$ ind. $\mathrm{m}^{-3}$, respectively.

Medium-sized animals were represented mainly by $\mathrm{CV}$ stage and adult Calanus chilensis, Centropages spp., Rhincalanus spp. and Eucalanus spp. At stations close to the coast $C$. chilensis was more abundant and Centropages spp. at oceanic stations. Almost all animals were more abundant in the 0 to $50 \mathrm{~m}$ layer, for example $C$. chilensis showed abundances ranging from 6 to 16 ind. $\mathrm{m}^{-3}$ in the 0 to 50 stratum, and from 0.1 to 3.2 ind. $\mathrm{m}^{-3}$ in the 50 to $150 \mathrm{~m}$ stratum. Centropages spp. was also more abundant within the upper $50 \mathrm{~m}$ of the water column (range 4 to 17 ind. $\mathrm{m}^{-3}$ ) with no clear temporal (non-El Niño/El Niño) pattern (Table 2).

Small-sized animals were numerically dominant (5093 to 22348 ind. $\mathrm{m}^{-2}$ in January 1997; 3251 to 28585 ind $\mathrm{m}^{-2}$ in July; 25079 to 70425 ind. $\mathrm{m}^{-2}$ in January 1998) and were represented by small calanoid cope- 
Table 2. Zooplankton composition and abundance (ind. $\mathrm{m}^{-3}$ ) at 2 coastal stations (15 and 3 ) in 2 depth strata during 3 periods: preEl Niño (30 January 1997), onset of El Niño (10 July 1997) and maximum of El Niño (27-29 January 1998). All samples were collected during the night (nd, no data). Small calanoid copepods include mainly Temora spp., Paracalanus spp. and Acartia spp.i appendicularians include mainly small-size Oikopleura spp., and chaetognaths mainly Sagitta spp.

\begin{tabular}{|c|c|c|c|c|c|c|}
\hline \multirow[t]{3}{*}{ Taxa } & \multicolumn{6}{|c|}{ Zooplankton abundance (ind. $\mathrm{m}^{-3}$ ) } \\
\hline & \multicolumn{2}{|c|}{ Stn 15 (30 Jan 97) } & \multicolumn{2}{|c|}{ Stn 15 (10 Jul 97) } & \multicolumn{2}{|c|}{$\operatorname{Stn} 3(27-29 \operatorname{Jan} 98)$} \\
\hline & $0-50 \mathrm{~m}$ & $50-150 \mathrm{~m}$ & $0-50 \mathrm{~m}$ & $50-150 \mathrm{~m}$ & $0-50 \mathrm{~m}$ & $50-150$ \\
\hline \multicolumn{7}{|l|}{ Large crustaceans } \\
\hline Euphausiids & 53.6 & 0.4 & 2.4 & 0.4 & 2.2 & 1.2 \\
\hline \multicolumn{7}{|l|}{ Medium-size crustaceans } \\
\hline Eucalanus/Rhincalanus spp. & 27.9 & 0.6 & 9.8 & 7.9 & 27.4 & 13.8 \\
\hline Calanus chilensis & 16.2 & 0.1 & 16.1 & 1.2 & 5.9 & 3.2 \\
\hline Centropages spp. & 5.6 & 0.8 & 16.8 & 1.1 & 3.7 & 2.2 \\
\hline Large calanoid copepods & nd & nd & 1.2 & 0.1 & 1.7 & 1.1 \\
\hline Medium calanoid copepods & nd & nd & 14.2 & 2.1 & 18.7 & 7.3 \\
\hline \multicolumn{7}{|l|}{ Small crustaceans } \\
\hline Small calanoid copepods & 132.3 & 2.3 & 209.6 & 31.5 & 303.9 & 136.4 \\
\hline Corycaeus spp. & 177.5 & 0.5 & 68.3 & 18.6 & 22.1 & 7.9 \\
\hline Oncaea spp. & 17.9 & 0.5 & 40.8 & 11.2 & 50.7 & 25.2 \\
\hline Oithona spp. & 0.6 & 0.1 & 17.4 & 5.5 & 60.2 & 17.7 \\
\hline \multicolumn{7}{|l|}{ Other groups } \\
\hline Appendicularians & 1.7 & 0.1 & 20.7 & 3.2 & 60.0 & 20.9 \\
\hline Chaetognaths & 15.1 & 0.2 & 9.8 & 2.9 & 65.8 & 29.4 \\
\hline
\end{tabular}

pods such as Temora spp., Acartia spp., Microcalanus spp., Paracalanus spp. and copepodites of genus Calanus, Centropages and Eucalanus/Rhincalanus. This group of small animals also includes the cyclopoid copepods, mainly represented by 3 genera: Corycaeus, Oncaea and Oithona. These animals did not show vertical migration and always remained within the upper $50 \mathrm{~m}$ of the water column. Abundances of small cyclopid copepods (Oncaea spp. and Oithona spp.) increased from 3 -fold to 1 order of magnitude (in the case of Oithona spp.) as the El Niño event proceeded from January 1997 to January 1998. The only exception was Corycaeus spp. which decreased in abundance from 178 to 22 ind. $\mathrm{m}^{-3}$ over the same period (Table 2).

Other zooplanktonic groups such as appendicularians (mainly small Oikopleura spp.) and chaetognaths (mainly Sagitta spp.) increased dramatically in abundance as the El Niño event proceeded, from 2 and 15 ind. $\mathrm{m}^{-3}$ during January 1997 to 60 and 66 ind. $\mathrm{m}^{-3}$ during January 1998, respectively (Table 2).

\section{Ingestion rates by zooplankton groups and grazing impact upon PP}

A total of 8,15 and 3 gut evacuation experiments were carried out in January and July 1997, and January 1998, respectively, the results of which are shown in Table 3.
During January 1997, euphausiids showed GCR constants of between 0.22 and $0.7 \mathrm{~h}^{-1}$. Their average IR was $156 \mu \mathrm{g} \mathrm{C}$ ind. ${ }^{-1} \mathrm{~d}^{-1}$ (Table 3), which represented $4 \%$ of their body carbon (Table 4 ). Large copepods showed an average GCR constant of ca $0.6 \mathrm{~h}^{-1}$ and an average IR of $36 \mu \mathrm{g} \mathrm{C}$ ind. ${ }^{-1} \mathrm{~d}^{-1}$, which represented $46 \%$ of their body carbon (Table 4 ). Small copepods gave GCR constants between 0.3 and $0.6 \mathrm{~h}^{-1}$, with an average IR of $22 \mu \mathrm{g} \mathrm{C}$ ind. ${ }^{-1} \mathrm{~d}^{-1}$ (Table 3 ), which represented $124 \%$ of their body carbon (Table 2 ).

During July, Euphausia mucronata showed a GCR constant of between 0.2 and $0.4 \mathrm{~h}^{-1}$. The average IR was $95 \mu \mathrm{g} \mathrm{C}$ ind. ${ }^{-1} \mathrm{~d}^{-1}$ (Table 3), which represented $12 \%$ of body carbon (Table 4 ). Large copepods had GCR constants of between 0.2 and $0.7 \mathrm{~h}^{-1}$. The average IR was $33 \mu \mathrm{g} \mathrm{C}$ ind.$^{-1} \mathrm{~d}^{-1}$ (Table 3 ), which represented $43 \%$ of the body carbon (Table 4 ). Similar values were obtained for January 1998 and are summarized in Tables 3 \& 4 .

Small copepods accounted for a large fraction of total crustacean zooplankton abundance: 82,86 and $91 \%$ during January 1997, July 1997 and January 1998, respectively. By contrast, they represented only a minor fraction of the total crustacean zooplankton carbon: 4,10 and $20 \%$ for the same periods, although they accounted for a relatively large fraction of total crustacean zooplankton grazing: 64,37 and $68 \%$, respectively (Table 5).

Euphausiids accounted for only a minor fraction of total crustacean zooplankton abundance: 7,5 and $1 \%$ 
during January 1997, July 1997 and January 1998, respectively, but they represented a large fraction of total crustacean zooplankton carbon: 73,63 and $28 \%$.
They also accounted for a relatively large fraction of total crustacean zooplankton grazing: 22,37 and 5\%, respectively (Table 5).

Table 3. Gut content, gut clearance rate (GCR) constant and ingestion rate estimated during the grazing experiment carried out during January and July 1997, and January 1998 in waters off Antofagasta (chl a-eq: chlorophyll a equivalents - the sum of chl $a$ and phaeopigments

\begin{tabular}{|c|c|c|c|c|c|c|c|}
\hline Station & Date & $\begin{array}{l}\text { Time } \\
\text { (h) }\end{array}$ & $\begin{array}{c}\text { Gut content } \\
\text { (ng chl a-eq ind }{ }^{-1} \text { ) }\end{array}$ & $\begin{array}{l}\mathrm{GCR} \\
\left(\mathrm{h}^{-1}\right)\end{array}$ & $\begin{array}{l}\text { C:chl a } \\
\text { ratio }\end{array}$ & $\begin{array}{l}\text { Ingestion rate } \\
\left(\mu g C \text { ind } .^{-1} \mathrm{~d}^{-1}\right)\end{array}$ & $r^{2}$ \\
\hline \multicolumn{8}{|c|}{ January 1997} \\
\hline \multicolumn{8}{|c|}{ Euphausia spp. (mean size $17 \mathrm{~mm}$ ) } \\
\hline 1 & $22 \operatorname{Jan} 97$ & $17: 00$ & 72.89 & 0.22 & 115 & 44.6 & 0.83 \\
\hline 15 & 14 Jan 97 & $03: 20$ & 55.91 & 0.70 & 169 & 159.5 & 0.42 \\
\hline \multirow[t]{3}{*}{24} & 19 Jan 97 & $01: 00$ & 34.38 & 0.41 & 86 & 29.2 & 0.76 \\
\hline & & & & & Average & 77.8 & \\
\hline & & & & & Corrected value & 155.6 & \\
\hline \multicolumn{8}{|c|}{ Large calanoid copepods (mainly CIV and adults of Calanus chilensis and Centropages spp.) } \\
\hline 24 & 19 Jan 97 & $01: 00$ & 3.70 & 0.52 & 86 & 4.0 & 0.76 \\
\hline \multirow[t]{3}{*}{15} & 14 Jan 97 & 03:20 & 3.93 & 0.64 & 169 & 10.2 & 0.69 \\
\hline & & & & & Average & 7.1 & \\
\hline & & & & & Corrected value $^{\mathrm{a}}$ & 35.5 & \\
\hline \multicolumn{8}{|c|}{ Small calanoid copepods (mainly Temora, Acartia, CII, CIII of Calanus and Centropages spp.) } \\
\hline 7 & $13 \mathrm{Jan} 97$ & $00: 40$ & 2.06 & 0.55 & 230 & 6.3 & 0.78 \\
\hline 19 & $17 \operatorname{Jan} 97$ & 01:00 & 0.94 & 0.32 & 378 & 2.8 & 0.61 \\
\hline \multirow[t]{3}{*}{10} & $13 \mathrm{Jan} 97$ & $15: 00$ & 1.53 & 0.65 & 174 & 4.2 & 0.51 \\
\hline & & & & & Average & 4.4 & \\
\hline & & & & & Corrected value & 22.0 & \\
\hline \multicolumn{8}{|c|}{ July 1997} \\
\hline \multicolumn{8}{|c|}{ Euphausia spp. (mean size $11 \mathrm{~mm}$ ) } \\
\hline 15 & 10 Jul 97 & $00: 15$ & 46.26 & 0.35 & 198 & 76.5 & 0.53 \\
\hline 7 & $01 \mathrm{Jul} 97$ & $20: 00$ & 33.60 & 0.22 & 240 & 43.2 & 0.75 \\
\hline 19 & $06 \mathrm{Jul} 97$ & $01: 00$ & 15.53 & 0.27 & 227 & 22.6 & 0.55 \\
\hline 27 & $04 \mathrm{Jul} 97$ & $14: 32$ & 32.76 & 0.26 & 127 & 25.6 & 0.83 \\
\hline 160 & 17 Jul 97 & $22: 30$ & 19.39 & 0.18 & 182 & 15.6 & 0.78 \\
\hline \multirow[t]{3}{*}{15} & 22 Jul 97 & $01: 12$ & 15.60 & 0.19 & 97 & 6.8 & 0.57 \\
\hline & & & & & Average & 31.7 & \\
\hline & & & & & Corrected value $^{a}$ & 95.1 & \\
\hline \multicolumn{8}{|c|}{ Large calanoid copepods (mainly CIV and adults of $C$. chilensis and Centropages spp.) } \\
\hline 15 & $10 \mathrm{Jul} 97$ & $00: 15$ & 3.07 & 0.72 & 198 & 10.5 & 0.89 \\
\hline C. front & 12 Jul 97 & $13: 12$ & 0.47 & 0.20 & 173 & 0.4 & 0.72 \\
\hline C. front & $11 \mathrm{Jul} 97$ & $23: 38$ & 0.33 & 0.59 & 107 & 0.5 & 0.83 \\
\hline C. front & 13 Jul 97 & $10: 43$ & 1.80 & 0.72 & 173 & 5.4 & 0.69 \\
\hline 15 & 09 Jul 97 & $23: 19$ & 0.46 & 0.59 & 244 & 1.6 & 0.73 \\
\hline 15 & 22 Jul 97 & $01: 12$ & 1.77 & 0.37 & 97 & 1.5 & 0.64 \\
\hline 15 & 10 Jul 97 & $00: 15$ & 2.71 & 0.50 & 198 & 6.4 & 0.94 \\
\hline 3 & $01 \mathrm{Jul} 97$ & $07: 50$ & 0.95 & 0.63 & 207 & 3.0 & 0.88 \\
\hline \multirow[t]{3}{*}{ C. front } & $11 \mathrm{Jul} 97$ & $23: 38$ & 0.49 & 0.69 & 107 & 0.9 & 0.94 \\
\hline & & & & & Average & 3.3 & \\
\hline & & & & & Corrected value & 33.0 & \\
\hline \multicolumn{8}{|c|}{ January 1998} \\
\hline \multicolumn{8}{|c|}{ Euphausia spp. (mean size $11 \mathrm{~mm}$ ) } \\
\hline 2 & 27 Jan 98 & $02: 50$ & 13.2 & 0.42 & 123 & 66.0 & - \\
\hline \multicolumn{8}{|c|}{ Large calanoid copepods (mainly C. chilensis, Eucalanus spp.) } \\
\hline 1 & 28 Jan 98 & $11: 15$ & 1.89 & 0.54 & 123 & 21.1 & - \\
\hline \multicolumn{8}{|c|}{ Small calanoid copepods } \\
\hline 2 & 26 Jan 98 & $18: 30$ & 0.49 & 0.50 & 123 & 5.1 & - \\
\hline
\end{tabular}




\section{Pelagic tunicates}

Salps

During January 1997, the integrated abundance (average \pm SD) of Salpa fusiformis was $311 \pm 488$ ind. $\mathrm{m}^{-2}(\mathrm{n}=$ $10)$, with a broad range covering from 0 (Stns 1 and 15) up to 1414 ind. $\mathrm{m}^{-2}$ (Stn 22). The average daily IR of the $S$. fusiformis population was estimated to be $126 \pm 196 \mathrm{mg} \mathrm{C} \mathrm{m}^{-2}$. On average, this species was able to remove $16 \pm 22 \%$ of the PP with a range of values from 0 to $60 \%$. Thus, we estimated that this species alone was able to remove approximately one-half of that grazed by the entire crustacean zooplankton community $(34 \%)$ during pre-El Niño conditions (January 1997). During El Niño conditions (July 1997 and January 1998) no S. fusiformis were found. Only tiny salps (mainly Thalia democratica) were present, and for this reason we did not compare these periods with January 1997.

\section{Appendicularians}

The integrated abundance (average \pm SD) of appendicularians in the whole study area remained similar during preEl Nino (January 1997; $587 \pm 535$ ind. $\mathrm{m}^{-2}$ ) and the onset of the El Niño event (July 1997; $474 \pm 453$ ), but it increased substantially as El Niño proceeded (January 1998; $4296 \pm 2007$ ) (Table 5). At coastal Stns 15 and 3. abundances in the 0 to $50 \mathrm{~m}$ stratum increased from 2 (January 1997) to 60 (January 1998) ind. $\mathrm{m}^{-3}$ (Table 2). The average daily IR of the appendicularians was estimated at $2 \pm 2(\mathrm{n}=10)$ and $16 \pm 7 \mathrm{mg} \mathrm{C} \mathrm{m}^{-2}$ during the same months. On average, this species was able to remove $0.2 \pm 0.1 \%$ of the PP during January and July 1997, and $1.4 \pm 0.9 \%$ of the PP during January 1998 (Table 5).

\section{DISCUSSION}

\section{Physical/chemical conditions}

Several different water masses occurred in the study area. STW was found between surface and $75 \mathrm{~m}$ depth. This water showed temperatures between 16 and $24^{\circ} \mathrm{C}$, salinities between 34.9 and 35.3 psu and dissolved oxygen contents between 4.5 and $5.5 \mathrm{ml} \mathrm{l}^{-1}$
(Silva \& Konow 1975, Robles et al. 1976). During winter SAW could be detected in the transition area between STW and SAW. The SAW was below the STW and its center of distribution deepened towards the north to a depth of between 75 and $125 \mathrm{~m}$. There was SSEW at between approximately 150 and $350 \mathrm{~m}$ depth which was characterized by a maximum in salinity and a minimum in dissolved oxygen content. The nucleus of this water mass showed temperatures of between 8 and $12^{\circ} \mathrm{C}$, salinities of between 34.4 and 34.9 psu and dissolved oxygen content of between 0.2 and $0.5 \mathrm{ml} \mathrm{l}^{-1}$ (Reid 1965, Silva \& Konow 1975). Upwelling of SSEW into the photic zone led to 'fertilisation' due to its high nutrient content, and it may thus have enhanced primary productivity in the vicinity of upwelling centers. Remote sensing (Thomas et al. 1994) and data collected during other field studies (Morales et al. 1996) have identified several localized upwelling centers, which are usually associated with capes and embayments such as Mejillones Bay (Rodríguez et al. 1991). During the present study, upwelled water rich in nutrients (SSEW) reached the surface only during the second grid in January 1997 and only quite close to the 
Table 5. Abundance, grazing rates and percentage of primary production ( $\mathrm{PP}, \mathrm{mg} \mathrm{C} \mathrm{m}^{-2} \mathrm{~d}^{-1}$ ) removed by large-size animals (euphausiids), medium-size animals (copepods, mainly adults and CIV, CV of Centropages spp., Eucalanus spp. and Calanus chilensis), small-size animals (calanoid and cyclopoid copepods), blastozoids of Salpa fusitormis and appendicularians (mainly Oikopleura spp.) in waters off Antofagasta during January and July 1997, and January 1998. Values are averages (SD in parentheses). Grazing rates of crustaceans were corrected according to Fig. 10 of Stevens \& Head (1998)

\begin{tabular}{|c|c|c|c|c|c|c|}
\hline & \multicolumn{2}{|c|}{$\begin{array}{l}\text { January } 1997 \\
\qquad(\mathrm{n}=10)\end{array}$} & \multicolumn{2}{|c|}{$\begin{array}{l}\text { July } 1997 \\
\quad(n=8)\end{array}$} & \multicolumn{2}{|c|}{$\begin{array}{l}\text { January } 1998 \\
\qquad(\mathrm{n}=6)\end{array}$} \\
\hline \multicolumn{7}{|c|}{ Abundance (ind. $\mathrm{m}^{-2}$ ) } \\
\hline Large animals & \multicolumn{2}{|c|}{$976.5(545.8)$} & \multicolumn{2}{|c|}{$575.8(660.4)$} & \multicolumn{2}{|c|}{$251.5(217.9)$} \\
\hline Medium animals & \multicolumn{2}{|c|}{$1606.6(2155.6)$} & \multicolumn{2}{|c|}{$1181.0(1783.5)$} & \multicolumn{2}{|c|}{$3935.7(978.2)$} \\
\hline Small animals & \multicolumn{2}{|c|}{$12016.2(6990.7)$} & \multicolumn{2}{|c|}{$10857.5(10008.5)$} & \multicolumn{2}{|c|}{$41579.0(16243.9)$} \\
\hline Salpa fusiformis & \multicolumn{2}{|c|}{$311.4(488.4)$} & \multicolumn{2}{|c|}{-} & \multicolumn{2}{|c|}{ - } \\
\hline Appendicularians & \multicolumn{2}{|c|}{$586.8(535.1)$} & \multicolumn{2}{|c|}{$474.4(453.5)$} & \multicolumn{2}{|c|}{$4296.0(2007.4)$} \\
\hline \multicolumn{7}{|c|}{ Grazing rate ( $\mathrm{mg} \mathrm{C}$ size-class ${ }^{-1} \mathrm{~d}^{-1}$ ) } \\
\hline & $\begin{array}{c}\text { Corrected } \\
\text { values }\end{array}$ & $\begin{array}{l}\text { Uncorrected } \\
\text { values }\end{array}$ & $\begin{array}{c}\text { Corrected } \\
\text { values }\end{array}$ & $\begin{array}{l}\text { Uncorrected } \\
\text { values }\end{array}$ & $\begin{array}{l}\text { Corrected } \\
\text { values }\end{array}$ & $\begin{array}{c}\text { Uncorrected } \\
\text { values }\end{array}$ \\
\hline Large animals & $92.9(51.9)$ & $31.0(17.3)^{\mathrm{d}}$ & $54.7(62.8\}$ & $18.3(20.9)$ & $16.6(14.4)$ & $4.1(3.6)$ \\
\hline Medium animals & $57.0(76.5)$ & $11.4(15.3)$ & $39.0(58.8)$ & $3.9(5.9)$ & $83.1(20.6)$ & $11.9(3.0)$ \\
\hline Small animals & $264.4(153.8)$ & $52.9(30.7)$ & $55.4(51.1)$ & $7.9(7.3)$ & $212.1(82.9)$ & $30.3(11.9)$ \\
\hline Salpa fusiformis & $125.5(196.8)$ & $125.5(196.8)$ & - & - & - & - \\
\hline Appendicularians & $2.2(2.0)$ & $1.1(1.0)$ & $1.8(1.7)$ & $0.9(0.8)$ & $15.9(7.4)$ & $8.0(3.7)$ \\
\hline \multicolumn{7}{|l|}{ Primary production } \\
\hline Available PP & \multicolumn{2}{|c|}{$2154.1(1912.8)$} & \multicolumn{2}{|c|}{$1576.0(766.3)$} & \multicolumn{2}{|c|}{$2333.3(2147.2)$} \\
\hline $\begin{array}{l}\% \text { PP removed by } \\
\text { crustaceans }\end{array}$ & $\begin{array}{l}33.9 \\
(28.4)\end{array}$ & $\begin{array}{c}7.8 \\
(6.3)\end{array}$ & $\begin{array}{l}10.0 \\
(8.3)\end{array}$ & $\begin{array}{c}3.9 \\
(2.8)\end{array}$ & $\begin{array}{l}25.9 \\
(20.3)\end{array}$ & $\begin{array}{c}3.8 \\
(2.9)\end{array}$ \\
\hline$\%$ PP removed by & 15.9 & 15.9 & - & - & - & - \\
\hline Salpa fusiformis & $(22.2)$ & $(22.2)$ & - & - & - & - \\
\hline $\begin{array}{l}\% \text { PP removed by } \\
\text { appendicularians }\end{array}$ & $\begin{array}{c}0.2 \\
(0.1)\end{array}$ & $\begin{array}{c}0.1 \\
(0.1)\end{array}$ & $\begin{array}{c}0.2 \\
(0.2)\end{array}$ & $\begin{array}{c}0.1 \\
(0.1)\end{array}$ & $\begin{array}{l}1.4 \\
(0.9)\end{array}$ & $\begin{array}{l}0.7 \\
(0.4)\end{array}$ \\
\hline
\end{tabular}

coast (Rutllant et al. 1998). In addition, gyres and filaments of cold water extending from the Mejillones Peninsula up to $200 \mathrm{~km}$ offshore occasionally appeared in association with local topography during January 1997 (González et al. 1998). We suggest that filaments, extending from coastal areas rich in POC and chl $a_{\text {, }}$ may act as vehicles for the transfer of organic matter (particulate and dissolved) to the oligotrophic ocean.

Several physical processes seem to occur at the study area, including:

(1) Upwelling centers probably strengthened by a combination of wind forcing and local topography factors.

(2) Gyres and filaments extending from the coast, and probably modulated by upwelling and topographic features such as the Mejillones Peninsula and the narrow continental shelf (González et al. 1998).

(3) The effect of El Nino conditions in July 1997 which compressed the upwelling lens to a very narrow coastal region and deepened the thermocline, so that upwelled water came from above the thermocline, and thus added few nutrients to the photic zone.

\section{Biological conditions}

Overall, concentrations of chl a were low at oceanic stations with values usually between 0.1 and $0.3 \mathrm{mg}$ $\mathrm{m}^{-3}$ and relatively high only at the stations close to the coast (within 5 to $10 \mathrm{n}$ miles) where surface ( $2 \mathrm{~m}$ depth) values were 5.0 and $1.5 \mathrm{mg} \mathrm{m}^{-3}$ during January and July 1997, respectively (Table 1). For the Antofagasta region, on other occasions a well-developed offshoreonshore gradient $\left(0.5\right.$ to $\left.2 \mathrm{mg} \mathrm{m}^{-3}\right)$ has been reported to occur within $37 \mathrm{~km}$ of shore (Thomas et al. 1994, Morales et al. 1996). During the present study, 76 to $88 \%$ of primary production could be attributed to picoand nanoplankton $(<23 \mu \mathrm{m}$ ) (González et al. 1998). In waters of the northern Humboldt Current ( 18 to $21^{\circ} \mathrm{S}$ ), it has been suggested that nanophytoplankton account for $>50 \%$ of phytoplankton biomass (Avaria et al. 1982), especially at offshore stations where chl a concentrations are low $\left(<1 \mathrm{mg} \mathrm{m}^{-3}\right.$ ) (Morales et al. 1996).

During both austral summer (January) and winter (July) of 1997 the chl a distribution showed a clear offshore-onshore gradient with values increasing from 30 
to $150 \mathrm{mg} \mathrm{m}^{-2}$. During January 1997 (Fig. 3B) high chI a concentrations occurred where there was cold water in the near surface coastal waters, suggesting the influence of the Ekman transport of upwelled waters (González et al. 1998). During July 1997, because of the El Niño event (Fig. 3C,D), higher chl a concentrations were always found close to or within embayments (Mejillones and Antofagasta Bays), where nutrients may have been provided from land (i.e. coastal cities) or via local resuspension. Even though wind-driven upwelling was observed, no nutrient enrichment occurred because only nutrient-depleted water from above the thermocline was brought to the surface (González et al. 1998). Low nutrient concentrations (i.e. $<4 \mu \mathrm{mol} \mathrm{NO}_{3} l^{-1}$, G. Daneri pers. comm. 1998) and the presence of abundant resting spores of ciatoms collected in sediment traps and water samples (González et al. in press) support this suggestion.

The mesoscale pattern of chl a distribution seems to have been influenced by several factors such as (1) wind-driven and/or topographically induced upwelling, (2) trapped coastal waves (S. Hormazabal pers. comm. 1998), and (3) the presence of eddies and filaments generated near the coast and propagating further offshore. These physical processes may keep particles within an area and enhance phytoplankton accumulation as seen in frontal areas (see Pingree et al. 1975).

POC showed a marked onshore-offshore gradient with higher concentrations near the coast (up to $15 \mathrm{~g}$ $\mathrm{m}^{-2}$ in January 1997 and $12 \mathrm{~g} \mathrm{~m}^{-2}$ in July 1997). The relatively low chl a concentrations measured in the whole study area (except coastal border) (Fig. 3), high phaeopigment concentrations (Table 1) and high C:chl a ratios (see Table 3) suggest that a large fraction of food available for zooplankton did not contain chl a.

A comparison of estimated daily respiration rates $(R)$ based on animal weight and water temperature derived for oceanic zooplankton (Ikeda 1985), and daily phytoplankton carbon based ingestion rates, suggested that during the 3 cruises ingestion of phytoplankton would have exceeded respiration rates for large and small calanoid copepods. Ingestion of phytoplankton alone would have failed to account for respiratory costs in the large animals (euphausiids) however (Table 6). For example, during January 1998, if we assume (IR/R) $/ 1.43$ (i.e. $70 \%$ of the ingested carbon is assimilated; Conover 1978), then the average phytoplankton carbon rations fell short of the minimum ration required for growth by ca $16 \%$ in the case of euphausiids. Dam et al. (1993) suggested that during the North Atlantic bloom experiment phytoplankton diet only contributed about $50 \%$ of the daily carbon and nitrogen rations of mesozooplankton. When we compare respiration rates with ingestion rates based

on total carbon (using the in situ C:chl a ratio at each station to convert IR into carbon ingestion), then IR could account for respiratory carbon demands in all cases.

We do not think that copepods and euphausiids would have been food-limited because many particles other than phytoplankton were available as food (see above). Boyd et al. (1980) reported that in upwelling

Table 6. Comparison of average rations of phytoplankton carbon (PPC) and total particulate organic carbon (POC) for January 1997 (non-El Niño), July 1997 and January 1998 (El Niño), and estimated respiration rate $(R)$ for large (euphausiids), medium (large calanoid copepods) and small (small calanoid and cyclopoid copepods) animals in waters off Antofagasta. Respiration rates were estimated according to Ikeda (1985): $\ln Y=0.5254+0.8354 \times \ln W+0.0601 \times T_{i}$ where $Y=\mu l \mathrm{O}_{2}$ ind $^{-1} \mathrm{~h}^{-1}, W=$ mg zooplankton carbon, $T=$ mean temperature $\left({ }^{\circ} \mathrm{C}\right)$ of the water column in the photic zone. Respiration rate was converted to carbon by the relationship $R=Y \times R Q \times 12 / 22.4$, where $R Q$, respiration quotient, was assumed to be equal to 1 (Omori \& Ikeda 1984). Ingestion rate based on PPC: A PPC: chl a ratio of 50:1 was assumed to convert this IR into units of PPC (Dubischar \& Bathmann 1997). Ingestion rate based on POC: the in situ POC:chl a ratio (average from the upper $50 \mathrm{~m}$ of the water column) was used to convert this IR into units of POC

Size class

Ingestion Respiration $I R / R \quad(\mathrm{IR} / R) /$ rate rate $1.43^{\mathrm{d}}$

$\left(\mathrm{IR} ; \mu g \mathrm{Cd}^{-1}\right)\left(R_{i} \mu \mathrm{gC} \mathrm{d}^{-1}\right)$

January 1997, IR based on PPC

Large animals 24998

Medium animals 21367

Small animals $\quad 58278$

17268

3812

5028

1.4

5.6

11.6

0.97

January 1997, IR based on POC

Large animals $\quad 92865$

Medium animals $\quad 57034$

Small animals 264356

17268

3812

5028

$\begin{array}{ll}5.4 & 3.77\end{array}$

$14.9 \quad 10.46$

$52.6 \quad 36.77$

July 1997, IR based on PPC

Large animals $\quad 14.740$

Medium animals 10983

Small animals 22345

July 1997, IR based on POC

Large animals $\quad 54759$

Medium animals $\quad 38973$

Small animals

55373

January 1998, IR based on PPC

Medium animals $\quad 33741$

Small animals $\quad 85569$

January 1998, IR based on POC

Large animals 16599

Medium animals $\quad 83043$

Small animals 212053

11107

2947

1994

1.3

(19)

11107

2947

1994

$4.9 \quad 3.44$

$13.2 \quad 9.24$

$27.8 \quad 19.42$

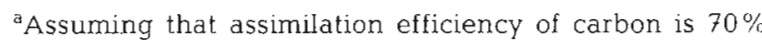
(Conover 1978), then $0.70 \times \mathrm{IR}=$ growth $+R$. If growth $=0$ then $I R / R=1.43$ 
areas off Peru, despite low concentrations of chl $a$, high concentrations of phaeophytin $\left(3.5 \mathrm{\mu g} \mathrm{l}^{-1}\right)$ were found. They suggested that upwelled waters bring detritus to the surface; thus, in these areas animals are mainly exposed to detritus (namely decomposed algal cells and faecal pellets) and not undamaged phytoplankton as available food. Our estimates of phaeopigments near the surface show low concentrations at oceanic stations (range 0.03 to $0.11 \mathrm{Mg}^{-1}$ ) and relatively high concentrations at coastal stations (range 0.4 to $2.4 \mu \mathrm{g}$ $\mathrm{l}^{-1}$ ) (Table 1). The presence of abundant phytodetritus near the coast is questionable because fluorometric determinations may overestimate the concentration of phaeophytin in the presence of phytoplankton, which contain chl $b$ (e.g. chlorophytes, prasinophytes) (Trees et al. 1985). We cannot disregard the possible interference of chl $b$-containing phytoplankton because abundances of microphytoflagellates were higher at coastal (Stn 15) than oceanic (Stn 120) stations: $1.1 \times 10^{7}$ and

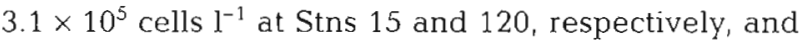
the same occurred for picophytoplankton abundances: $4.8 \times 10^{6}$ and $3.1 \times 10^{5}$ cells $\mathrm{l}^{-1}$, respectively (A. Troncoso pers. comm. 1999).

Microscopical observation of both euphausiid and copepod faecal pellets, containing lorica of tintinnids, thecate dinoflagellates and crustacean remains (González et al. in press), support the idea that zooplankton might be able to fill their daily rations at low in situ chl a concentrations. Even though chl a concentrations measured in the present study were significantly lower than those reported for upwelling areas off Peru (2 to $20 \mathrm{mg} \mathrm{m}^{-3}$, Barber \& Chavez 1983), POC values were comparable in both areas. Off Peru animals were always exposed to $<150 \mathrm{mg} \mathrm{C} \mathrm{m}^{-3}$ (Boyd et al. 1980), as occurred off Antofagasta (Fig. 5). These authors reported that the ranking of copepod dietary biomass was: nanoplankton $>$ dinoflagellates $>$ microzooplankton $>$ diatoms, in an environment where the dominant particle size class was $<5 \mu \mathrm{m}$ in diameter.

\section{IR expressed as daily percent body carbon (\%BC)}

During January 1997 there was a negative relationship between IR as \% BC and animal size: the minimum value was $4 \%$ for large euphausiids $(17 \mathrm{~mm}$ length) and the maximum was $124 \%$ for small calanoid copepods (0.8 to $1.7 \mathrm{~mm}$ length) (Table 4). Estimations of the GCR constant for cyclopoid copepods (not shown) did not fit a negative exponential curve $\left(\mathrm{r}^{2}=\right.$ $0.2)$, suggesting that copepods may have had continued feeding on faecal material in the experimental chamber because of their coprophagous behavior (González \& Smetacek 1994). In order to estimate the grazing rate in cyclopoid copepods, an ingestion rate of $35 \% \mathrm{BC} \mathrm{d}^{-1}$ was assumed (Lampitt \& Gamble 1982 , Drits \& Semenova 1984)

In euphausiids, higher values of IR as \%BC were found during July 1997 (12\%) than during January 1997 (4\%). This might be because only juvenile euphausiids were found during July $(11 \mathrm{~mm}$ average length), so that results cannot be compared with those obtained during January 1997 (17 mm average length). Small calanoid copepods ingested approximately their body carbon daily, while in large copepods the IR as $\%$ BC ranged from $27 \%$ (January 1998) to $46 \%$ (January 1997) (Table 4). Daily rations for copepods (genera Eucalanus, Undinula, Centropages and Temoral from the Florida continental shelf varied from 1 to $14 \% \mathrm{BC}$ $\mathrm{d}^{-1}$ (Kleppel et al. 1996), 7 to $18 \% \mathrm{BC} \mathrm{d}^{-1}$ for largesized copepods from the Barents Sea (Bamstedt et al. 1992) and between 0.9 and $2.8 \% \mathrm{BC} \mathrm{d}^{-1}$ for Calanus chilensis, Eucalanus inermis and Centropages brachiatus from the Peru upwelling system (Dagg et al. 1980).

\section{Zooplankton assemblages and grazing impact on PP}

Copepods were restricted to the upper $50 \mathrm{~m}$ layer (Table 2), where oxygen concentrations exceeded $0.5 \mathrm{ml} \mathrm{l}^{-1}$ (Fig. 2B). Similar patterns have been reported for the copepod genera Calanus (i.e. Calanus chilensis) and Centropages from the upwelling area off Peru, where they tended to be found in waters having $>0.8$ and $0.2 \mathrm{ml} \mathrm{O}_{2} \mathrm{l}^{-1}$, respectively (Boyd et al. 1980).

Euphausiids (mainly Euphausia mucronata and E. eximia) seem to play an important role in the Humboldt Current trophic webs, being the preferred food of several species of fishes, whales and birds (Antezana 1970). Adult anchovy from the southern part of Peru feed mainly on E. mucronata, Calanus chilensis, Centropages spp. and Oncaea spp. (Rojas de Mendiola 1980). Euphausiids displayed conspicuous vertical migrations to reach the upper $50 \mathrm{~m}$ of the water column during the night, a stratum where most of the phyto- and zooplankton were concentrated; however, the vertical displacement depends on natatory capacity, which is a function of body size. Size-frequency distributions of euphausiids showed that samples collected during the day are dominated by animals in the size range of 1 to $5 \mathrm{~mm}$ while those collected in the 50 to $150 \mathrm{~m}$ stratum are dominated by animals in the 5 to $10 \mathrm{~mm}$ size range. Only in samples collected during the night was it possible to collect individuals in the size range of 10 to $20 \mathrm{~mm}$ in both 0 to 50 and 50 to $150 \mathrm{~m}$ strata. Echosound observations of the movement of the deep scattering layer showed that these animals travelled from ca $300 \mathrm{~m}$ depth to the upper 0 to $50 \mathrm{~m}$ layer in a time of ca $1 \mathrm{~h}$. Day versus 
night catches conducted at the time-series Stn 15 (29 January to 1 February 1997) indicated that the integrated (upper $150 \mathrm{~m}$ of the water column) grazing activity of the euphausiid population was, on average, 2 -fold greater during the night $\left(142 \mathrm{mg} \mathrm{C} \mathrm{d}^{-1}\right.$; range 42 to $407 \mathrm{mg} \mathrm{C} \mathrm{d}^{-1}$ ) than during the day (78 $\mathrm{mg} \mathrm{C} \mathrm{d}^{-1}$; range 20 to $152 \mathrm{mg} \mathrm{C} \mathrm{d}^{-1}$ ). These figures suggest that during January 1998, the euphausiid population would be able to remove from 1 to $7 \%$ of the total PP during the day and from 2 to $19 \%$ of PP during the night.

Our results indicate that crustacean zooplankton showed a moderate grazing impact, removing $34 \%$ $(\mathrm{SD}=28 \%, \mathrm{n}=10), 10 \%(\mathrm{SD}=8, \mathrm{n}=7)$ and $26 \%(\mathrm{SD}=$ $20, n=5$ ) of PP during January and July 1997, and January 1998, respectively (Table 5). For other areas of the world's oceans, mesozooplankton accounted for 19 to $39 \%$ (Southern California Bight, Landry et al. 1994), 1 to $17 \%$ (Sargasso Sea: Roman et al. 1993) and 1 to $5 \%$ (North Atlantic: Morales et al. 1991, Dam et al. 1993). Also, females of copepods (Calanus chilensis, Eucalanus inermis and Centropages brachiatus) consumed $<5 \%$ of PP in the Peru upwelling system (Dagg et al. 1980). In the Southern Ocean, grazing by copepods was very low and accounted for $<1 \%$ of PP (Dubischar \& Bathmann 1997). In the equatorial Pacific, mesozooplankton grazing removed from 1 to $12 \%$ of PP and showed no apparent differences between normal upwelling and El Niño periods (Dam et al. 1995).

Crustacean IRs were also estimated using gut pigment and compared with literature data. Gut pigment estimates of IR are controversial due to the finding that pigment losses to colorless, non-fluorescent compounds occur (reviewed in Tirelli \& Mayzaud 1998). We, therefore, applied a correction factor to our gut pigment estimates of IR using the relationship between real and apparent IR reported in Stevens \& Head (1998). These authors modelied the kinetics of chl a destruction in Calanus spp.; we used their model although we realize that many assumptions need to be made since the zooplankton, phytoplankton and temperature were different in both studies. Because of uncertainty about how precise or biased the correction factors are, we also compared our estimates with IRs of crustaceans reported for the Humboldt (central Chile), Peru and Benguela upwelling systems (Table 7). IR estimates for euphausiids are well within the range reported for other upwelling regions. For the large calanoid copepods our estimate lay within the upper range reported in the literature, while for the small calanoid copepods, our estimates were higher (by a factor of 2 to 10 ) than those reported for the Benguela and Peru upwelling regions (Table 7). These differences might be due to the fact that only in the present study was a correction factor applied and it increased our estimations by a factor 5 to 10 (see Table 3). If we had used average values of IR from Table 7 , instead of the data obtained during the present study (Table 3), the IR of euphausiids would be in the range of 50 to 385,29 to 227 and 13 to $99 \mathrm{mg} \mathrm{C}$ size-class ${ }^{-1} \mathrm{~d}^{-1}$ for January and July 1997, and January 1998, respectively, which is similar to the range obtained during this study for January and July 1997: 47 to $319 \mathrm{mg}$ C size-class ${ }^{-1} \mathrm{~d}^{-1}$ (Table 7 ). Using literature data (Table 7), we estimated that the IR of the small copepods would have increased dramatically from January (64 $\mathrm{mg} \mathrm{C}$ size-class ${ }^{-1} \mathrm{~d}^{-1}$ ) and July 1997 (58 mg C sizeclass $\left.^{-1} \mathrm{~d}^{-1}\right)$, to January $1998\left(220 \mathrm{mg} \mathrm{C}\right.$ size-class $\left.{ }^{-1} \mathrm{~d}^{-1}\right)$. These figures are quite close to the corrected IRs estimated during this study for July 1997 (55 mg C sizeclass $^{-1} \mathrm{~d}^{-1}$ ) and January 1998 (212 $\mathrm{mg} \mathrm{C}$ size-class ${ }^{-1}$ $\left.\mathrm{d}^{-1}\right)$, and 4 -fold lower with respect to January 1997 (264 mg C size-class ${ }^{-1} \mathrm{~d}^{-1}$ ) (Table 5).

Salps normally feed continuously (Madin 1974) and may potentially reduce the phytoplankton stock greatly. Because salps can capture particles down to $1 \mu \mathrm{m}$ in size (Harbison \& Gilmer 1976), they should also affect pico- and nanophytoplankton, as well as microzooplankton such as athecate dinoflagellates and tintinnids. Salps are indiscriminate feeders. Copepod parts, and even whole pteropods, have frequently been observed in the guts of salps (Silver 1971, Madin 1974), and in the Southern Ocean krill larvae are often found in the guts of Salpa thompsoni (cited in Huntley et al. 1989). Because of the above characteristics of salps, it is important to estimate the potential grazing impact of these pelagic tunicates. The gut-content method (Madin \& Cetta 1984) seems to give results that are close to probable in situ feeding rates (Madin \& Kremer 1995). For a $7 \mathrm{~cm} S$. fusiformis we measured a

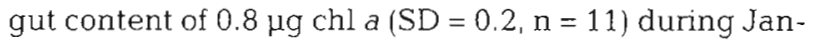
uary 1998; in the same area (near Stns 1 and 3); however, we were unable to measure the GCR constant because of methodological problems (i.e. containers of adequate size for the maintenance of these large animals).

The high variability show by salps results from their highly patchy distribution. During this study we found Salpa fusiformis abundance to range from 0 to 14 ind. $\mathrm{m}^{-3}$; however, aggregations of $>700$ salps $\mathrm{m}^{-3}$ have been observed in waters off Ireland (Bathmann 1988). The grazing impact of only 1 species of salp can remove even more than $100 \%$ of daily PP, i.e. Cyclosalpa bakeri in the subarctic Pacific (Madin et al. 1997) or S. thompsoni in the Southern Ocean (Dubischar \& Bathmann 1997).

During January 1997, the grazing impact of Salpa fusiformis (as the percentage of PP removed) was estimated to be either twice (16 and $8 \%$, respectively) or one-half (16 and $34 \%$, respectively) as much as the 
impact of crustaceans (copepods plus euphausiids), depending on whether uncorrected or corrected grazing rate values for crustaceans were used (Table 5). Because of the uncertainties of the correction method (see above), we also compared this information using literature data on crustacean IRs (Table 7). The grazing impact of $S$. fusiformis ( $16 \%$ ) lies almost in the middle of the range for crustaceans ( 7 to $23 \%$ ), showing that

Table 7. Carbon-based estimation of ingestion rate of euphausiids (large animals) and copepods (medium and small animals) from different localities (mainly from the Humboldt, Benguela, California and Peru upwelling systems)

\begin{tabular}{|c|c|c|c|c|}
\hline Taxa & Locality & $\begin{array}{l}\text { Filtration rate } \\
\left(\mathrm{ml} \text { ind }{ }^{-1} \mathrm{~h}^{-1}\right)\end{array}$ & $\begin{array}{l}\text { Carbon-based } \\
\text { ingestion rate } \\
\left(\mu \mathrm{g} C \text { ind }-^{-1} \mathrm{~d}^{1}\right)^{a}\end{array}$ & Source \\
\hline \multicolumn{5}{|l|}{ Large animals } \\
\hline $\begin{array}{l}\text { Euphausia superba } \\
(250 \mathrm{mg} \text { dry wt) }\end{array}$ & $\begin{array}{l}\text { US Palmer Station, } \\
\text { Southern Ocean }\end{array}$ & $25-300$ & $60-720$ & Antezana et al. (1982) \\
\hline E. superba (230 mg dry wt) & Laboratory conditions & $40-198$ & $96-475$ & Kato et al. (1979) \\
\hline E. pacifica (12 mg dry wt) & Puget Sound & $15-125$ & $36-300$ & Ohman (1984) \\
\hline E. pacifica (3-5 mg dry wt) & California Current & $12-38$ & $29-91$ & Lasker (1966) \\
\hline E. lucens ( $3-5 \mathrm{mg}$ dry wt) & Benguela upwelling region & - & $34-623^{b}$ & Stuart \& Pillar (1990) \\
\hline E. mucronata (11 mg dry wt $)^{c}$ & $\begin{array}{l}\text { Humboldt up- } \\
\text { welling region }\end{array}$ & - & $58-319$ & $\begin{array}{l}\text { Present study } \\
\text { (January 1997) }\end{array}$ \\
\hline E. mucronata (2 mg dry wt $)^{\complement}$ & $\begin{array}{c}\text { Humboldt } \\
\text { upwelling region }\end{array}$ & - & $47-230$ & $\begin{array}{l}\text { Present study } \\
\text { (July 1997) }\end{array}$ \\
\hline Average $\left(\mathrm{SD}_{\mathrm{i}} \mathrm{n}\right)$ & & & $\begin{array}{c}51-394 \\
(22-223 ; \mathrm{n}=7)\end{array}$ & \\
\hline Taxa & Locality & $\begin{array}{l}\text { Chl a-based } \\
\text { filtration rate } \\
\text { (ng ind }{ }^{-1} d^{-1} \text { ) }\end{array}$ & $\begin{array}{l}\text { Carbon-based } \\
\text { ingestion rate } \\
\left(\mu \mathrm{g} \mathrm{C} \text { ind } .^{-1} \mathrm{~d}^{-1}\right)\end{array}$ & Source \\
\hline \multicolumn{5}{|l|}{ Medium animals } \\
\hline $\begin{array}{l}\text { Calanus chilensis } \\
\text { C. brachiatus }\end{array}$ & $\begin{array}{c}\text { Peru upwelling } \\
\text { system }\end{array}$ & $0-72.0$ & $\begin{array}{c}0-7.1 \\
(\operatorname{mean}=3.6)\end{array}$ & Boyd et al. (1980) \\
\hline $\begin{array}{l}\text { C. chilensis } \\
\text { C. patagoniensis }\end{array}$ & $\begin{array}{l}\text { Concepción Bay, } \\
\text { central Chile }\end{array}$ & $\begin{array}{l}- \\
-\end{array}$ & $\begin{array}{l}41.0 \\
16.5\end{array}$ & Castro et al. (1991) \\
\hline $\begin{array}{l}\text { C. chilensis } \\
\text { C. brachiatus }\end{array}$ & $\begin{array}{l}\text { Dichato Bay, } \\
\text { central Chile }\end{array}$ & $\begin{array}{r}151.3 \\
81.6\end{array}$ & $\begin{array}{l}25.3^{\mathrm{b}} \\
13.6^{\mathrm{b}}\end{array}$ & Peterson et al. (1988) \\
\hline $\begin{array}{l}\text { Large copepods (mainly } \\
\text { Calanus and Centropages } \\
\text { spp.) }\end{array}$ & $\begin{array}{l}\text { Humboldt } \\
\text { upwelling } \\
\text { system }\end{array}$ & - & $\begin{array}{l}35.5 \\
33.0 \\
21.1\end{array}$ & $\begin{array}{l}\text { Present study } \\
\text { (January 1997) } \\
\text { (July 1997) } \\
\text { (January 1998) }\end{array}$ \\
\hline Average $(S D ; n)$ & & & $\begin{array}{c}23.7 \\
(12.5 ; n=8)\end{array}$ & \\
\hline \multicolumn{5}{|l|}{ Small animals } \\
\hline Paracalanus spp. & Benguela upwelling region & $23-24$ & $3.9^{\mathrm{b}}$ & $\begin{array}{l}\text { Peterson et al. (1989) } \\
\text { (fide Verheye et al. 1992) }\end{array}$ \\
\hline Paracalanus spp. & Benguela upwelling region & $9-15$ & $2.0^{\circ}$ & Peterson et al. (1990) \\
\hline P. denudatus (adult female) & Peru upwelling region & - & 1.2 & Dagg et al. (1980) \\
\hline P. denudatus (CIII) & Experimental data & - & 0.6 & Paffenhöfer (1982) \\
\hline P. denudatus (adult female) & Experimental data & - & 2.6 & Paffenhöfer (1982) \\
\hline $\begin{array}{l}\text { Small calanoid copepods } \\
\text { (mainly Temora spp., Acartia } \\
\text { spp. and Paracalanus spp.) }\end{array}$ & $\begin{array}{l}\text { Humboldt } \\
\text { upwelling } \\
\text { system }\end{array}$ & - & $\begin{array}{r}22.0 \\
5.1 \\
5.1\end{array}$ & $\begin{array}{l}\text { Present study } \\
\text { (January 1997) } \\
\text { (July 1997) } \\
\text { (January 1998) }\end{array}$ \\
\hline Average $(S D ; n)$ & & & $\begin{array}{c}5.3 \\
(6.9 ; n=8)\end{array}$ & \\
\hline
\end{tabular}


approximately the same results were obtained by 2 different calculation procedures.

The most common appendicularian species found during the present study was Oikopleura dioica. Average abundance of appendicularians was a maximum of $31 \pm 18$ ind. $\mathrm{m}^{-3}$ during January 1998 (El Niño), with values ranging from 5 to 90 ind. $\mathrm{m}^{-3}$. Appendicularians increased their contribution to total zooplankton carbon from $0.5 \%$ during January 1997 (pre-El Niño) to $6 \%$ during January 1998 (El Nin̄o) (Fig. 7B). The grazing impact of appendicularians estimated as a percentage of PP removed per day was low and ranged from $0.2 \%$ during January and July 1997 to $1.4 \%$ during January 1998 (Table 5). Other species of the genus Oikopleura such as $O$. vanhoeffeni removed $<1.4 \%$ of daily particle production during the spring diatom bloom and from 4 to $10 \%$ during the post-bloom crash in Logy Bay, Newfoundland (Deibel 1988), and $O$. dioica and Stegosoma magnum removed from 5 to ca $100 \%$ of the daily production in sub-tropical waters (Alldredge 1981), indicating that at times the grazing impact of appendicularians can be important.

Our results suggest that the dramatic decrease in zooplankton biomass estimated in the coastal area of $f$ Antofagasta during July 1997 (Fig. 7 A) might be a consequence of a marked seasonal change, with low zooplankton biomass values in winter, as has been reported in waters off Peru (Carrasco \& Santander 1987). It seems that the El Niño effect may have introduced only minor changes to the total zooplankton biomass, as measurements of zooplankton biomass (mg dry wt $\mathrm{m}^{-3}$ ) conducted in January 1998 (average \pm SD; $24.6 \pm$ $19, \mathrm{n}=16$ ) indicated no significant differences with respect to January $1997(21.4 \pm 14, \mathrm{n}=5$ ) (Fig. 7A). In terms of size-distribution of zooplankton, a gradual increase in the contribution of small-size (copepods and appendicularians) and large-size copepods to total zooplankton biomass was observed concomitant with a decrease in the contribution of euphausiids to total zooplankton carbon (Fig. 7B). For example, small-size copepods increased their average biomass in terms of carbon from $46 \mathrm{mg} \mathrm{C} \mathrm{m}^{-2}$ in January 1997 to $141 \mathrm{mg} \mathrm{C}$ $\mathrm{m}^{-2}$ in January 1998. Also, euphausiids decreased their average biomass from $777 \mathrm{mg} \mathrm{C} \mathrm{m}^{-2}$ in January 1997 to $195 \mathrm{mg} \mathrm{C} \mathrm{m} \mathrm{m}^{-2}$ in January 1998.

Our results suggest that during El Niño conditions (January 1998), a larger amount of the generated PP was channelled through ingestion by small-size animals than during pre-El Niño conditions (January 1997) in coastal waters off Antofagasta. During El Niño events a positive thermal anomaly might impose stress conditions to several planktonic communities. It has been shown that stress tends to reduce the average size of the organisms in communities (Rodriguez \& Mullin 1986). Such a shift may be the result of a transi- tory competitive advantage of small, opportunistic species or the result of size-selective predation of large individuals (Kerfoot 1974, Steele \& Frost 1977). Our observations support the former explanation: a concomitant shift in the size spectrum of phytoplankton towards small sizes (nano- and picoplankton) was observed in the study area (González et al. 1998). The dominance of pico-and nanoplankton would favor the development of organisms capable of catching such tiny prey. Small-size calanoid and cyclopoid copepods and pelagic tunicates (i.e. larvaceans or salps) might satisfy such requirements. Predation of chitinous zooplankton by gelatinous carnivorous organisms was very high because huge numbers of siphonophores and chaetognaths were found. However, we discard the idea of a size shift because of selective predation on large-size organisms because we also studied the diet of carnivore gelatinous organisms (siphonophores, medusael and found mainly cyclopoid and small-size calanoid copepods as the main food items ( $F$. Pagès unpubl. data). A fact that would favor a selective shift towards large-size organisms.

Acknowledgements. We acknowledge the skilful help of the captain and crew of the RV 'Abate Molina'. Valuable comments and suggestions from Don Deibel (Memorial Univ. of Newfoundland, Canada) and C. Morales (Univ. de Concepción, Chile) improved an earlier version of this manuscript. We are indebted to J. L. Iriarte, G. Pizarro and G. Daneri for use of their primary production data in Table 5. Thanks to G. Asencio, L. Castro, P. Mejias, V. Ortiz, L. Rodríguez, J. Torres, $M$. Inostroza and C. Vera for help during field and laboratory work. We thank C. Lorenzen (AWI) for processing the POC filters. This research was supported by a grant from the Fondo Nacional de Desarrollo Científico y Tecnológico (FondecytChile) to H.E.G. (Fondecyt Sectorial No. 5960002-1996). The cruise conducted during January 1998 was partially funded by the FONDAP, Oceanografía y Biología Marina Humboldt Program.

\section{LITERATURE CITED}

Acuña JL, Deibel D (1994) Feeding experiments with living oikopleurid tunicates in the northeast Greenland polynya. EOS, Trans Am Geophys Un 75:127 (abstract)

Alldredge AL (1981) The impact of appendicularian grazing on natural food concentrations in situ. Limnol Oceanogr $26: 247-257$

Andersen V (1985) Filtration and ingestion rates of Salpa fusiformis Cuvier (Tunicata: Thaliacea): effects of size, individual weight and algal concentration. J Exp Mar Biol Ecol 87:13-29

Antezana T (1970) Eufáusidos de la costa de Chile. Su rol en la economía del mar. Rev Biol Mar 14:19-27

Antezana T, Ray K, Melo C (1982) Tropic behavior of Euphausia superba Dana in laboratory conditions. Polar Biol 1: $77-82$

Arntz W, Fahrbach E (1996) El Nin̄o: Experimento Climático de la Naturaleza. Fondo de Cultura Económica, Mexico DF 
Avaria S, Muñoz P (1987) Effects of the 1982-1983 El Niño on the marine phytoplankton off Northern Chile. J Geophys Res 92:14,369-14,382

Avaria S, Muñoz P, Uribe E (1982) Composición y biomasa del fitoplancton marino del norte de Chile en Diciembre de 1980 (operación oceanográfica MARCHILE XI-ERFEN II). Cienci Tecnol Mar, CONA 6:5-36

Båmstedt U, Eilertsen HC, Tande KS, Slagstad D, Skjoldal H $R$ (1992) Copepod grazing and its potential impact on the phytoplankton development in the Barents Sea. Polar Res 10:339-353

Barber RT, Chavez FP (1983) Biological consequences of El Nin̄o. Science 222:1203-1210

Bathmann UV (1988) Mass occurrence of Salpa fusiformis in the spring of 1984 off Ireland: implications for sedimentation processes. Mar Biol 97:127-135

Bodungen v B, Wunsch M, Fürderer H (1991) Sampling and analysis of suspended and sinking particles in the northern North Atlantic. In: Hurd DC, Spencer DW (eds) Marine particles: analysis and characterization. Geophys Monogr 63:47-56

Boyd CM, Smith SL, Cowles TJ (1980) Grazing patterns of copepods in the upwelling system off Peru. Limnol Oceanogr 25:583-596

Carrasco S, Santander H (1987) The El Niño event and its influence on the zooplankton off Peru. J Geophys Res 92: $14,405-14,410$

Castro LR, Bernal PA, González HE (1991) Vertical distribution of copepods and the utilization of the chlorophyl $a^{-}$ rich layer within Concepcion Bay, Chile. Estuar Coastal Shelf Sci 32:243-256

Conover RC (1978) Transformation of organic matter. In Kinne $O$ (ed) Marine ecology, Vol 4. John Wiley, New York, p 221-499

Dagg $M$, Cowles T, Whitledge T, Smith S, Howe S, Judkins D (1980) Grazing and excretion by zooplankton in the Peru upwelling system during April 1977. Deep-Sea Res 27A: $43-59$

Dam HG, Miller CA, Jonasdottir SH (1993) The trophic role of mesozooplankton at $47^{\circ} \mathrm{N}, 20^{\circ} \mathrm{W}$ during the North Atlantic Bloom Experiment. Deep-Sea Res 40:197-212

Dam HG, Zhang X, Butler M, Roman M (1995) Mesozooplankton grazing and metabolism at the equator in the central Pacific: implications for carbon and nitrogen fluxes. Deep-Sea Res Part II Top Stud Oceanogr 42:735-756

Deibel D (1988) Filter feeding by Oikopleura vanhoeffeni: grazing impact on suspended particles in cold ocean waters. Mar Biol 99:177-186

Deibel D (1997) Feeding and metabolism of appendicularians. In: Bone $Q$ (ed) Biology of pelagic tunicates. Oxford University Press, Oxford, p 93-101

Drits AV, Semenova TN (1984) Experimental investigations of the feeding of Oithona similis Claus. Oceanology (Wash) $24: 755-759$

Dubischar C, Bathmann U (1997) Grazing impact of copepods and salps on phytoplankton in the Atlantic sector of the Southern Ocean. Deep-Sea Res 44:415-433

Escribano R, Irribarren C, Rodríguez L (1997) Influence of food quantity and temperature on development and growth of the marine copepod Calanus chilensis from northern Chile. Mar Biol 128:281-288

González HE, Smetacek V (1994) The possible role of the cyclopoid copepod Oithona in retarding vertical flux of zooplankton faecal material. Mar Ecol Prog Ser 113 $233-246$

González HE, Daneri G, Figueroa D, Iriarte J, Lefevre N, Pizarro G, Quiñones R, Sobarzo M, Troncoso A (1998) Pro- ducción primaria y su destino en la trama trófica pelágica y océano profundo e intercambio océano-atmósfera de $\mathrm{CO}_{2}$ en la zona norte de la Corriente de Humboldt $\left(23^{\circ} \mathrm{S}\right)$ : Posibles efectos del evento El Niño 1997-98. Rev Chil Hist Nat 71:429-458

González HE, Ortiz V, Sobarzo M (in press) The role of faecal material in particulate organic carbon flux in the northern Humboldt Current $\left(23^{\circ} \mathrm{S}\right)$ before and during the 1997-1998 El Niño. J Plankton Res

Harbison GR, Gilmer RW (1976) The feeding rates of the pelagic tunicate Pagea confoederata and two other salps. Limnol Oceanogr 21:517-528

Head EJH, Harris LR (1996) Chlorophyll destruction by Calanus spp. grazing on diatoms: kinetics, effect of ingestion rate and feeding history, and a mechanistic interpretation. Mar Ecol Prog Ser 135:223-235

Huntley ME, Sykes PF, Marin V (1989) Biometry and trophodynamics of Salpa thomsoni Foxton (Tunicata: Thaliacea) near the Antactic Peninsula in austral summer, 1983-1984. Polar Biol 10:59-70

Huyer A, Smith RL, Paluszkiewicz T (1987) Coastal upwelling off Peru during normal and El Niño times, 1981-1984. J Geophys Res 92:14,297-14,307

Ikeda $\mathrm{T}$ (1985) Metabolic rates of epipelagic marine zooplankton as a function of body size and temperature. Mar Biol 85:1-11

Kato M, Murano M, Segawa S (1979) Estimates of the filtration rate of the Antarctic krill under laboratory conditions. Trans Tokyo Univ Fish 3:107-112

Kerfoot WC (1974) Net accumulation rates and the history of cladoceran communities. Ecology 55:51-61

Kleppel GS (1993) On the diets of calanoid copepods. Mar Ecol Prog Ser 99:183-195

Kleppel GS, Burkart CA, Carter K, Tomas C (1996) Diets of calanoid copepods on the West Florida continental shelf: relationships between food concentration, food composition and feeding activity. Mar Biol 127:209-217

Lampitt RS, Gamble JC (1982) Diet and respiration of the small planktonic marine copepod Oithona nana. Mar Biol 66:185-190

Landry MR, Lorenzen CJ, Peterson WK (1994) Mesozooplankton grazing in the Southern California Bight. II. Grazing impact and particulate flux. Mar Ecol Prog Ser 115:73-85

Lasker R (1966) Feeding, growth, respiration and carbon utilization of a euphausiid crustcean. J Fish Res Board Can 23:1291-1317

Mackas D, Bohrer R (1976) Fluorescence analysis of zooplankton gut contents an investigation of diel feeding patterns. J Exp Mar Biol Ecol 25:77-85

Madin LP (1974) Field observations on the feeding behavior of salps (Tunicata: Thaliacea). Mar Biol 25:143-147

Madin LP, Cetta CM (1984) The use of gut fluorescence to estimate grazing by oceanic salps. J Plankton Res 6: $475-492$

Madin LP, Deibel D (1998) Feeding and energetics of Thaliacea. In: Bone $Q$ (ed) The biology of pelagic tunicates. Oxford University Press, Oxford, p 81-103

Madin LP, Kremer P (1995) Determination of the filter-feeding rates of salps (Tunicata, Thaliacea). ICES J Mar Sci 52: $583-595$

Madin LP, Purcell JE (1992) Feeding, metabolism, and growth of Cyclosalpa baken in the subarctic Pacific. Limnol Oceanogr 37:1236-1251

Madin LP, Purcell JE, Miller CB (1997) Abundance and grazing effects of Cyclosalpa bakeri in the subarctic Pacific. Mar Ecol Prog Ser 157:175-183 
Mann KH (1992) Physical influences on biological processes: How important are they? S Afr J Mar Sci 12:107-121

Mianzan HW, Mari N, Prenski B, Sanchez F (1996) Fish predation on neritic ctenophores from the Argentine continental shelf: a neglected food resource? Fish Res (Amst) 27:69-79

Morales C, Bedo A, Harris RP, Tranter PR (1991) Grazing of copepods assemblages in the north-east Atlantic: the importance of the small size fraction. J Plankton Res 13 : $455-472$

Morales C. Blanco J, Braun M, Reyes H, Silva N (1996) chlorophyll-a distribution and associated oceanographic conditions in the upwelling region off northern Chile during the winter and spring 1993. Deep-Sea Res 43:267-289

Ohman MD (1984) Omnivory by Euphausia pacifica: the role of copepod prey. Mar Ecol Prog Ser 19:125-131

Omori M, Ikeda $T$ (1984) Methods in marine zooplankton ecology. John Wiley, New York

Paffenhöfer GA (1982) Grazing by copepods in the Peru upwelling. Deep-Sea Res 29:145-147

Pagès F, González HE, González SR (1996) Diet of the gelatinous zooplankton in Hardangerfjord (Norway) and potential predatory impact by Aglantha digitale (Trachymedusae). Mar Ecol Prog Ser 139:69-77

Parsons TR, Takahashi M, Hargrave B (1984) Biological oceanographic processes, 3rd edn. Butterworth-Heinemann Ltd, Oxford

Parsons TR, Maita Y, Lalli CM (1992) A manual of chemical and biological methods for seawater analysis. Pergamon Press, Oxford

Petersen WT (1989) Zooplankton feeding and egg production in comparison to primary production along the west coast of South Africa. Proceedings of the Plankton Dynamics Mini-Symposium, Cape Town. May 1989. Rep Benguela Ecol Progm S Afr 17:1-5

Peterson WT, Arcos DF, McManus GB, Dam H, Bellantoni D, Johnson $T$, Tiselius $P(1988)$ The nearshore zone during coastal upwelling: daily variability and coupling between primary and secondary production off central Chile. Prog Oceanogr 20:1-40

Peterson WT, Painting SJ, Hutchings L (1990) Diel variations in gut pigment content, diel vertical migration and estimates of grazing impact for copepods in the southern Benguela upwelling region in October 1987. J Plankton Res 12:259-281

Pingree RD, Pugh P, Holligan P, Forster G (1975) Summer phytoplankton blooms and red tides along tidal fronts in the approaches to the English Channel. Nature 258:672-677

Reid JL (1965) Intermediate waters of the Pacific Ocean. Johns Hopkins Oceanogr Stud 2:1-85

Robles F, Alarcón E, Ulloa A (1976) Water masses at the northern Chilean zone and their variations during cold period (1967) and warm periods (1969, 1971-1973). El Niño workshop, Guayaquil, Ecuador, December 1974. FAO Fish Rep 185:94-196

Rodríguez J, Mullin M (1986) Diel and interannual variation of size distribution of oceanic zooplanktonic biomass Ecology 67:215-222

Editorial responsibility: Otto Kinne (Editor),

Oldendorf/Luhe, Germany
Rodriguez L, Marín V, Farías M, Oyarce E (1991) Identification of an upwelling zone by remote sensing and in situ measurements. Mejillones del Sur Bay (Antofagasta, Chile). Sci Mar 55:467-473

Rojas de Mendiola B (1980) Summary of the studies about food and feeding habits of the anchovy (Engraulis ringens). IOC Workshop Report No, 28, Intergovernmental Oceanographic Commission, Paris, p 221-231

Roman MR, Dam HG, Gausens AL, Napp JM (1993) Zooplankton biomass and grazing at the JGOFS Sargasso Sea time series station. Deep-Sea Res 40:883-901

Rutllant J, Fuenzalida $H$, Torres R, Figueroa D (1998) Interacción océano atmósfera-tierra en la región de Antofagasta (Chile, $23^{\circ} \mathrm{S}$ ): Experimento DICLIMA. Rev Chil Hist Nat 71:405-427

Shannon LV, Pillar SC (1986) The Benguela ecosystem. 3. Plankton. In: Barnes $M$ (ed) Oceanography and marine biology. An Annual Review 24. University Press Aberdeen, p 65-170

Silva N, Konow D (1975) Contribución al conocimiento de las masas de agua en el Pacífico Sudoriental. Expedición KRILL. Crucero 3-4 Julio-Agosto 1974. Rev Com Perm Pacifico Sur 3:63-75

Silver MW (1971) The habitat of Salpa fusiformis in the California Current as described by stomach content studies and the effect of salp swarms on the food supply of the plankfon community. PhD thesis, University of California, San Diego

Steele JH (1974) The structure of marine ecosystems. Harvard University Press, Cambridge, MA

Steele JH, Frost BW (1977) The structure of planktonic communities. Trans R Soc Lond 280:485-534

Stevens CJ, Head EJH (1998) A model of chlorophyll a destruction by Calanus spp. and implications for the estimation of ingestion rates using the gut fluorescence method. Mar Ecol Prog Ser 171:187-198

Strub PT, Mesias J, Montecino V, Rutllant J, Salinas S (1998) Coastal ocean circulation off western South America. In: Robinson AR, Brink KH (eds) The global ocean. Regional Studies and Syntheses. Wiley, New York, p 273-314

Stuart V, Pillar SC (1990) Diel grazing patterns of all ontogenetic stages of Euphausia lucens and in situ predation rates on copepods in the southern Benguela upwelling region. Mar Ecol Prog Ser 64:227-241

Thomas A, Strub T, Huang F, James C (1994) A comparison of the seasonal and interannual variability of phytoplankton pigment concentration in the Peru and California Current systems. J Geophys Res 99:7355-7370

Tirelli V, Mayzaud P (1998) Gut pigment destruction by the copepod Acartia clausi. J Plankton Res 20:1953-1961

Trees CC, Kennicutt MC, Brooks JM (1985) Errors associated with the standard fluorometric determination of chlorophylls and phaeopigments. Mar Chem 17:1-12

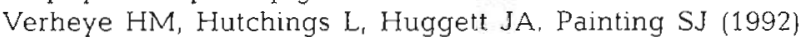
Mesozooplankton dynamics in the Benguela ecosystem, with emphasis on the herbivorous copepods. S Afr J Mar Sci $12: 561-584$

Submitted: October 16, 1998, Accepted: August 17, 1999 Proofs received from author(s): March 10, 2000 